\title{
Cenozoic stratigraphy of Taiwan: Window into rifting, stratigraphy and paleoceanography of South China Sea
}

\author{
HUANG Chi-Yue ${ }^{1}$, YEN Yi ${ }^{1}$, ZHAO QuanHong ${ }^{2} \&$ LIN Chiou-Ting ${ }^{1}$ \\ ${ }^{1}$ Key Laboratory of Marginal Sea Geology, Guangzhou Institute of Geochemistry, Chinese Academy of Sciences, Guangzhou 510640, China; \\ ${ }^{2}$ State Key Laboratory of Marine Geology, School of Ocean and Earth Sciences, Tongji University, Shanghai 200092, China
}

Received September 1, 2011; accepted June 8, 2012

\begin{abstract}
Shallow marine sequences of the northern South China Sea (SCS) are uplifted and exposed by plate convergence in the Taiwan mountain belt. These deposits provide detailed geological information about the rifting event, stratigraphy, sedimentology, paleoclimate and paleoceanography of the shallow SCS to compare with what are recorded in the ODP 1148 deep-sea core. Seismic surveys and marine micropalentological studies show that Eocene sequences in the offshore Taiwan Strait and onland Taiwan mountain belt are all deposited in rifting basins and are covered unconformably by the Late Oligocene-Neogene post-rifting strata. Between syn-rifting and post-rifting sequences, there is a regional break-up unconformity throughout the island. Early Oligocene and Late Eocene strata are missing along the break-up unconformity equivalent to the $\mathrm{T}_{7}$ unconformity in the Pearl River Mouth Basin off south China. This may suggest that the SCS oceanic crust could have initiated between 33 and 39 Ma. Neither obvious stratigraphic gap nor slumping features are found in the Oligocene-Miocene transition interval of Taiwan. This observation highly contrasts with what has been documented from the ODP 1148 deep-sea core. This suggests that the stratigraphic gap and slumping features could only be recorded in the SCS deep sea region, but not in the shallow shelf near Taiwan. Compared to the Middle Miocene paleoceanographic re-organization events in the SCS deep sea, the geological history of the Taiwan shallow sequence shows changes of in sedimentation and faunal composition. Due to the Antarctic glacial expansion at $14 \mathrm{Ma}$, Middle to late Miocene strata of the Western Foothills show progressive regression sedimentations associated with a decrease of benthic foraminiferal abundance and a sharp faunal turnover event. Many Early-Middle Miocene endemic benthic foraminifers were extinct in 14-13 Ma and new benthic foraminifers of the Kuroshio Current fauna appeared from 10.2 Ma, comparable with new occurrence of Modern benthic foraminifers at $9 \mathrm{Ma}$ in the Java Sea area. This reveals that the Western Boundary Kuroshio Current in the North Pacific could initiate from 10-9 Ma due to closures of the Indo-Pacific seaways by convergent tectonics between the Australian Continent and the Indonesian Arc in 12-8 Ma. Subduction of the SCS oceanic lithosphere since the Middle Miocene resulted in formation of the Hengchun Ridge accretionary prism and the North Luzon Arc. Occurrence of these two bathymetric highs $(-2400 \mathrm{~m})$ since the Middle Miocene and closures of the inter-arc passages in the North Luzon arc in the last 3.5 Ma would control the water exchanges between the West Pacific and the deep SCS. Accordingly, the tectonic evolution in the Central Range-Hengchun Peninsula accretionary prism and the arc-forearc Coastal Range not only control directly the route for water exchanges between the West Pacific and the SCS, but also indirectly shows a great influence on the geochemistry of deep SCS waters. The latter is best shown by much negative carbon isotope values of benthic foraminifers in the ODP 1148 deep-sea core than the West Pacific records in the last 14 Ma.
\end{abstract}

Taiwan, Cenozoic stratigraphy, South China Sea, geological records, ODP Site 1148

Citation: Huang C Y, Yen Y, Zhao Q H, et al. Cenozoic stratigraphy of Taiwan: Window into rifting, stratigraphy and paleoceanography of South China Sea. Chin Sci Bull, 2012, 57: 3130-3149, doi: 10.1007/s11434-012-5349-y

The South China Sea (SCS) represents one of the large marginal seas in the low latitude West Pacific. It is charac-

*Corresponding author (email: Huangcy@mail.ncku.edu.tw) terized by a young oceanic crust (Late Oligocene to middle Miocene) [1], occurrence of both passive and active continental margins and high sedimentation rates. The Pearl River Mouth (PRMB) in the northern SCS was developed 
by normal faulting during the Late Mesozoic-Early Cenozoic on the passive southern Asian continental margin [2]. The Paleogene syn-rifting basin is filled by lacustrine-lake deposits and finally covered unconformably by Neogene post- rifting strata. After the formation of syn-rifting basins, due to thermal upwelling from mantle magma, basalts are erupted along E-W-trending MOR (magnetic lineaments of $\mathrm{C}_{11}-\mathrm{C}_{5 \mathrm{~d}}$ ) and new oceanic crust is born in the SCS deep ba$\sin$ [3]. Soon after sessions of spreading in the Middle Miocene, the SCS oceanic lithosphere subducted eastward beneath the West Philippine Sea Plate along the Manila Trench [4]. The subduction develops an active continental margin with an accretionary prism and a volcanic arc between Taiwan and Luzon Islands and the SCS is thus progressively semi- closed since then.

Due to lack of land exposures, most studies of the subseafloor SCS geology rely upon geophysical methods or using cuttings and limited cores obtained by costly drillings. This limitation hampers efforts of direct stratigraphic observation and also multiple analyses using a same rock sample to look into some fundamental scientific issues concerning the SCS tectonics from its opening to semi-closing.

Taiwan Island represents the exposed accretionary prism developed by eastward subduction of the SCS oceanic lithosphere beneath the Philippine Sea Plate since the Middle Miocene [5,6] (Figure 1). During subduction, sequences on the passive northeastern SCS shelf-slope were scrapped off into the accretionary prism and further deformed and uplifted during the following oblique arc-continent collision in the last $6.5 \mathrm{Ma}$ [7]. Therefore, Taiwan Island provides one of the best geological windows looking into the details of shallow SCS geology. Taiwan Island connects northward to the East China Sea, the SCS to the southwest, the Luzon Strait to the south and the Huatung Basin to the east (Figure 1). The N-S-trending Taiwan Island is $370 \mathrm{~km}$ in length and $140 \mathrm{~km}$ in maximum width. The main structures strike in NNE-SSW and turn to NE-SW in northeastern part and in $\mathrm{N}-\mathrm{S}$ direction in the southern part of the island (Figure 1). The Taiwan mountain belt belongs to a part of the active earthquake-volcanism belt of the North Pacific. There are two opposing trenches. In the SW, the Eurasian continent, led by the SCS oceanic lithosphere, subducts eastward along the Manila Trench beneath the Philippine Sea Plate, while in the NE the latter subducts northward along Ryukyu Trench beneath the rifting Eurasian continent (Figure 1). The Manila subduction system is actively constructing the Taiwan mountain belt, while the Ryukyu Trench system plays a destructing role to collapse the Taiwan mountain belt. Taiwan Island can be divided into five morphotectonic units, from west to east, the Coast Plain, Western Foothills, Hsúehshan Range, Central Range and Coastal Range (Figure 1). According to geological setting, these units can be further grouped into three tectonic domains before onset of the arc-continent collision at 6.5 Ma: (1) fold-and-thrust belt in the passive continental margin (Coast Plain, Western
Foothills, Hsúehshan Range), (2) accretionary prism (Hengchun Peninsula-Central Range), and (3) forearc basin-volcanic arc (Coastal Range) in the active margin (Figure 1).

The Cenozoic history of Taiwan includes three main orogenies: normal faulting in Early Cenozoic to develop Paleocene-Eocene rifting basins on the Late Paleozoic (?)Mesozoic pre-rifting basement [8]; eastward subduction of the SCS oceanic lithosphere beneath the Philippine Sea Plate since the Middle Miocene to develop an active continental margin (including the Hengchun Ridge accretionary prism, North Luzon Trough forearc basin and North Luzon Arc [6,9]); and in the last $6.5 \mathrm{Ma}$ oblique collision between the North Luzon Arc and the underthrusting Eurasian continent margin [7] to give birth to the present Taiwan Island.

East of the Lishan-Laonung fault, the Central RangeHengchun Peninsula marks the accretionary prism, which is further composed of three units of (1) Late Paleozoic(?)Mesozoic marble, schist, gneiss (Tananao Group), (2) Eocene metamorphosed sandstone-slate in the eastern part of the Central Range, and (3) Miocene slope turbidite-slate in the western part of the Central Range and the Hengchun Peninsula (Figures 1 and 2). Before the arc-continent collision at $6.5 \mathrm{Ma}$, the stratigraphy west of the Lishan-Laonung fault was the Asian passive continental margin comprising of the Mesozoic basement (only found beneath the Peikang Basement High and the Taiwan Strait by drilling), Paleogene syn-rifting sequences and Late Oligocene-Neogene post-rifting strata (Figure 2). The passive margin strata are all deposited in upper slope-shallow shelf-swamp environments. These were thrust westward and deformed into a fold-and-thrust belt during the oblique arc-continent collision since the Latest Miocene. The Coastal Range in eastern Taiwan is composed of Miocene-Pliocene volcanic arc and Pliocene-Pleistocene forearc turbidite sequences (Figure 2).

The time of oceanic crust formation and the mechanism responsible for its semi-closure are two fundament scientific interests in the study of the SCS geology. In addition, changes of SCS land-sea configurations and a complicated tectonic history boarding the SCS, also have great influence on changes of sediment sources and fluctuations of paleoclimate-paleoceanography records as well. The purposes of this paper are to review the characteristics of stratigraphic sequence, faunal and sedimentological records in Cenozoic sequences exposed in the Taiwan mountain belt to compare with stratigraphic records in the ODP 1148 deep-sea core during the last $32 \mathrm{Ma}$ [10-15]. The main topic focuses on: (1) the geological time of break-up unconformity to infer the onset formation event of the SCS oceanic crust, (2) any stratigraphic gap and/or slumping features that might occur in Oligocene/Miocene boundary to understand areas influenced by a MOR ridge jump at the paleomagnetic $\mathrm{C}_{7}$ event, (3) paleoceanography and faunal changes in the shallow SCS shelf in response to paleoceanography re-organization in the deep SCS since the Middle Miocene, and (4) the geological relationship between tectonic evolution of the Taiwan 


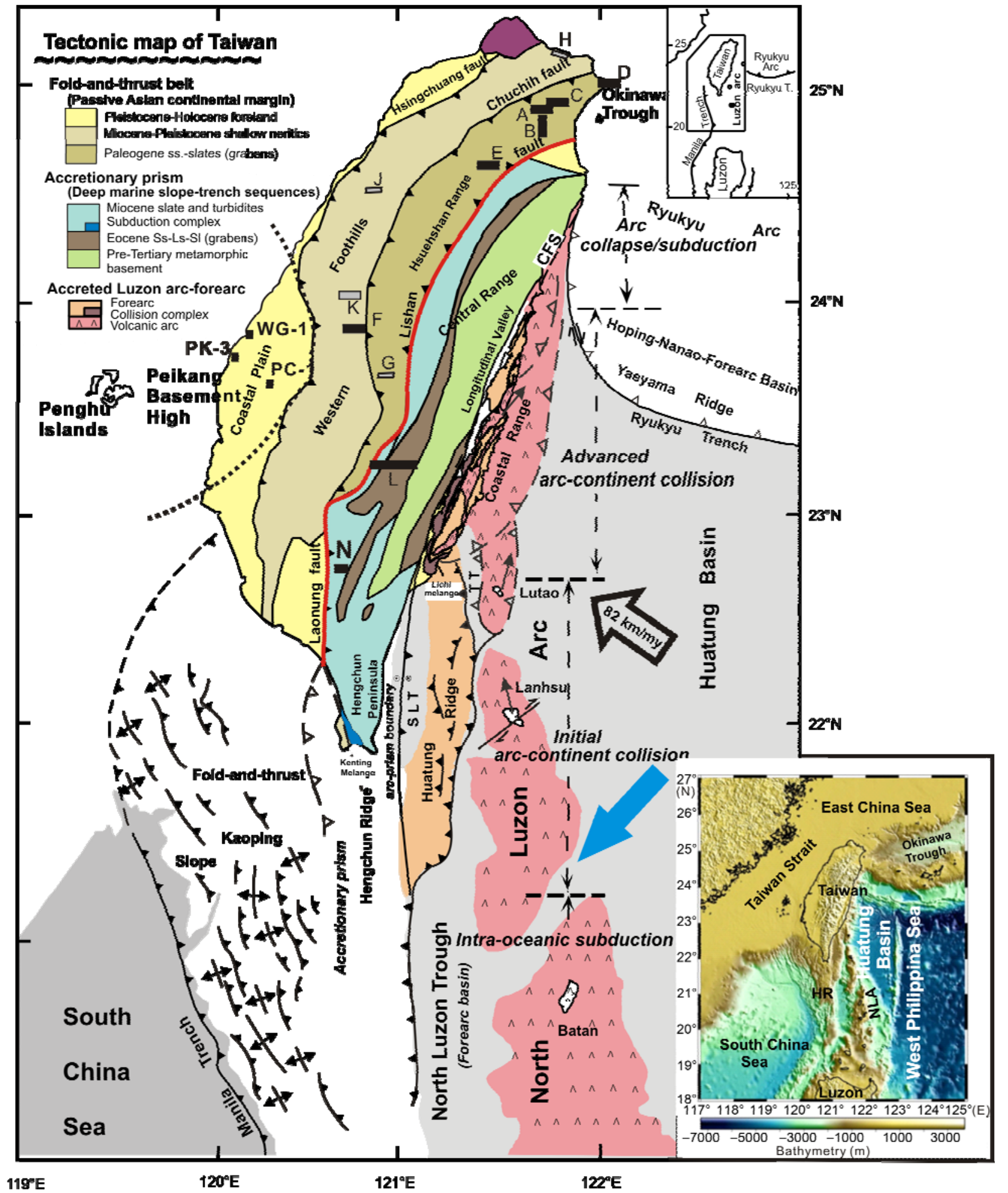

Figure 1 Tectonic setting of Taiwan and locations of study sections. Four tectonic processes are now operating onland Taiwan and its offshore regions. From south to north they are: intra-oceanic subduction, initial arc-continent collision, advanced arc-continent collision and arc collapse/subduction. These processes also represented four stages of the Taiwan tectonic evolution occurring in 16-6.5, 6.5-1, <1 and $0 \mathrm{Ma}$, respectively [5-7]. A, Peishihchi section; B, Nanshihchi section; C, Pei-I Highway section; D, Lungtung Cap section; E, Northern-Cross-Island Highway section; F, Kuohsing Peikangchi section; G, Junkeng section; H, Keelung Waimulu section; J, Miaoli Chuhuangkeng section; K, Nantou Tsukeng anticline section; L:Southern-Cross-Island Highway section; N: Nantawushan; HR: Hengchun Ridge accretionary prism; NLA: North Luzon Arc; TT, Taitung Trough; WG-1, PC-1 and PK-3 are drilling wells. Black arrow shows the vector of the Philippine Sea Plate movement relative to the Eurasian continent. Blue arrow marks the inter-arc passage between the Lanyu volcanic island and the Batan volcanic island as the main entrance of the Pacific Deep Water flowing westward into the SCS deep basin. 


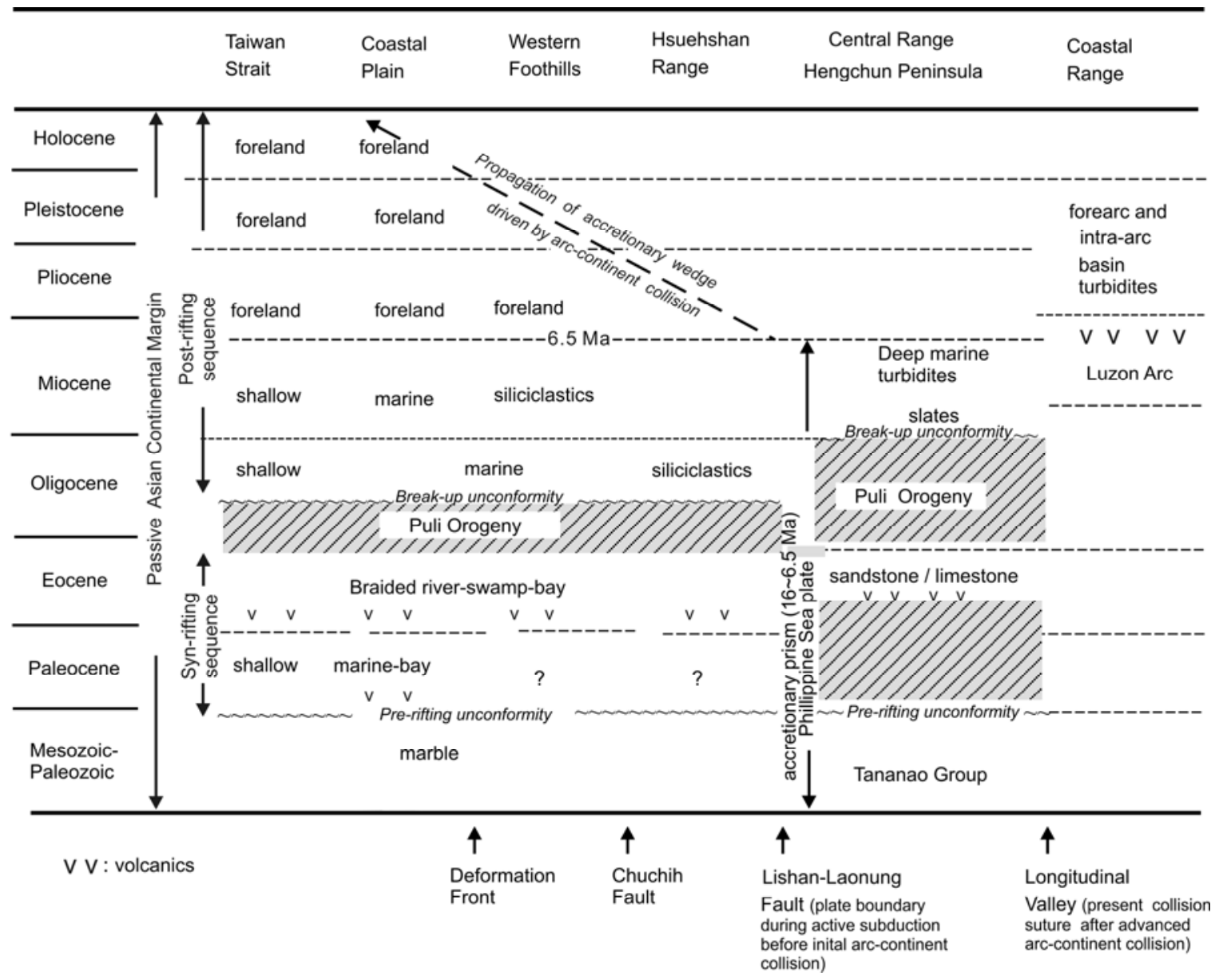

Figure 2 Tectonostratigraphy of Taiwan (modified from [6]).

mountain belt and records of paleoceanographic events in the deep SCS.

When new oceanic crust forms by rifting the adjacent passive continental margin (for examples, the Atlantic Ocean, the northern Australia continental margin and the SCS), always has three stratigraphic sequences: pre-rifting basement sequence, syn-rifting sequence in normal-fault-bounded graben and post-rifting strata deposited after rifting event. These sequences are separated from each other by the pre-rifting unconformity and the break-up unconformity. In addition to the break-up unconformity, crust thinning causes syn-rifting eruptions of basic volcanic rocks. This provides another criterion in addition to the break-up unconformity to recognize syn-rifting sequences in the deformed mountain belt. In the following sections we integrate multiple stratigraphic evidence including published data and preliminary highlights of current research to show that there is a regional break-up unconformity throughout Taiwan Island. This unconformity can be found in passive and active margins, or in the subsurface drilling and exposed land sections of mountain belts. The break-up unconformity in the Taiwan region is compared with what has been documented from the PRMB in the northern SCS to provide an age estimation of the earliest formation event $\mathrm{n}$ of the SCS oceanic crust.

\section{Taiwan Cenozoic stratigraphy infers the onset age of SCS oceanic crust formation}

\subsection{Taiwan Strait and the Coastal Plain}

Seismic investigations over the offshore Taiwan Strait and the onland Coastal Plain show that there are Paleogene rifting basins bounded by normal faults [8,16]. Drillings in the offshore Penghu Basin further prove that the Paleogene synrifting sequence is comprised of marine shale dominant sediments of the Middle Eocene age (Zones NP15-16 of calcareous nannofossils; Figure 3) and thick volcanics. The Eocene syn-rifting sequence is unconformably covered by the Miocene post-rifting strata (Figure 3). In the Peikang Basement High (Figure 1; NE extension of the Dongsha Uplift in the northeastern SCS), Early Miocene post-rifting strata overlie unconformably on the Middle Eocene volcanics (44.1 $\pm 2.2 \mathrm{Ma}$ by K-Ar dating) [17] and sandstone-shale (Well PC-1; Figure 1), or on the Paleocene shallow- marine strata (Well WG-1 [18]; Figures 1 and 3), or even covered directly on the Cretaceous pre-rifting basement of the Peikang 


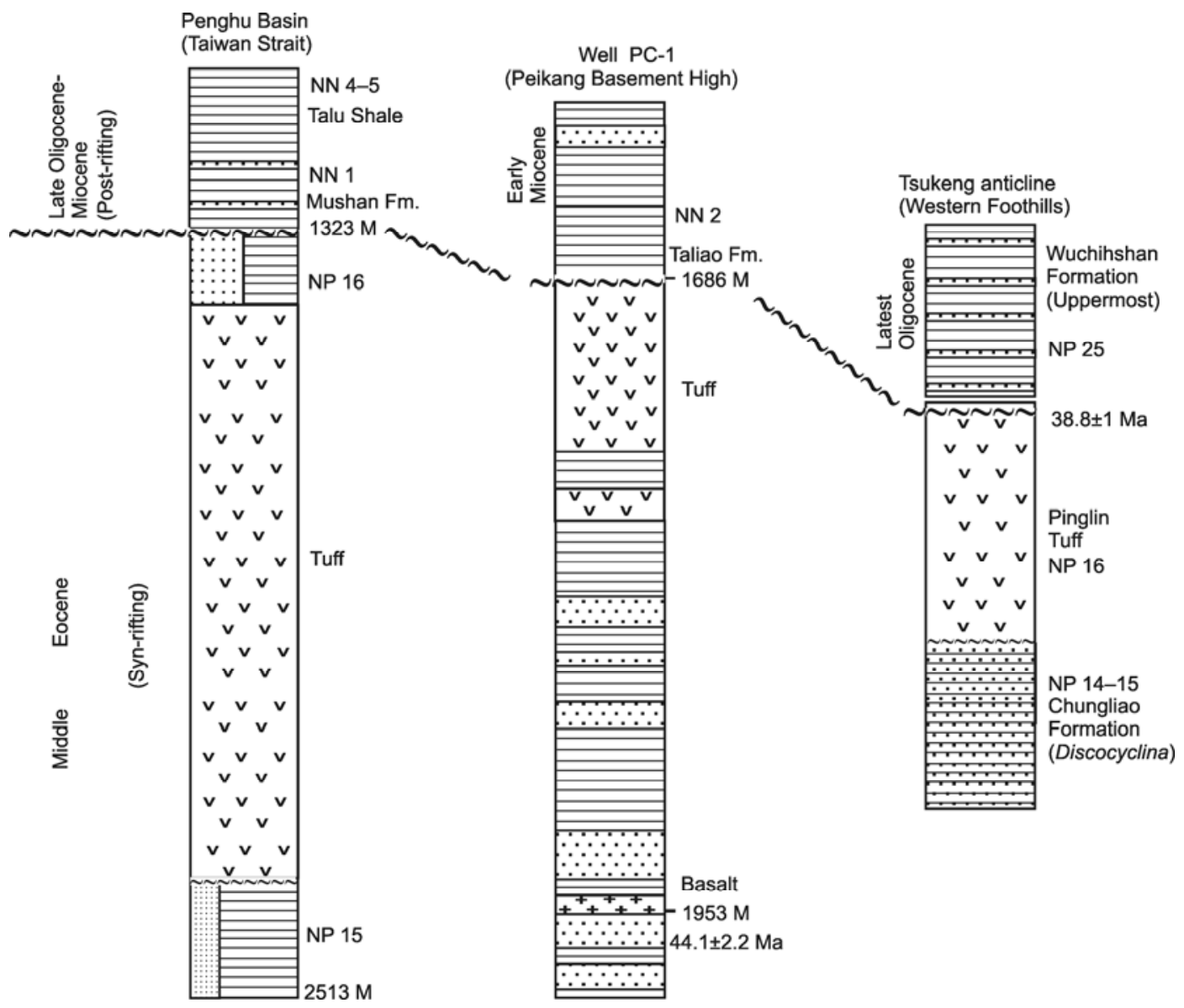

Figure 3 Correlation of subsurface stratigraphy in the Penghu Basin [16] offshore Taiwan Strait, well PC-1 [17] above the Peikang Basement High beneath the Coastal Plain and exposed strata in the Tsukeng anticline section [19-21], Western Foothills, central Taiwan. The Wavy line marks the regional break-up unconformity between the Eocene syn-rifting strata and the Late Oligocene-Miocene post-rifting sequence.

Basement High [8](Well PK-3, Figure 1).

\subsection{Western Foothills}

In the last century, the Taiwan geological community regarded the late Oligocene Wuchihshan Formation as the lowest strata exposed in the Western Foothills (Figure 4). The Wuchihshan Formation is mainly exposed in the Waimulu section ( $\mathrm{H}$ in Figure 1) along the northern coast west of the Keelung Harbor. In northern Taiwan, the lower part of the Wuchihshan Formation is always cut by a thrust fault. Consequently, it is unknown what is beneath this formation. However, the current study on the stratigraphy exposed in the axial part of the Tsukeng anticline near Nantou, central Taiwan ( $\mathrm{K}$ in Figure 1), indicates that there are Middle Eocene strata unconformably underlying the latest Oligocene Wuchihshan Formation (only the uppermost part) [19-21]. These Middle Eocene strata are deposited in a rifting basin (named as the Nantou Basin [19-21]), revealing a similar basin character between the Western Foothills onland Taiwan and the Penghu Basin offshore Taiwan Strait.

The strata exposed in the axial part of the Tsukeng anticline were previously considered as the Early Miocene
(Tsukeng Formation) (Figure 5) [22,23]. However, a detailed stratigraphic study proves that sequences exposed in the anticline are composed of three independent lithostratigraphic units in ascending order: the latest Oligocene $\mathrm{Wu}-$ chihshan Formation (only uppermost part), the Middle Eocene Pinglin Tuff and the Chungliao Formation (Figure 5). The Wuchihshan Formation is conformably overlain by the Earliest Miocene Mushan Formation, Early Miocene Taliao Formation and younger strata. The Taliao Formation contains planktic foraminifers of Zone N5 and benthic foraminifers of Gaudryina pseudohayasakai Zone and Gaudryina kokuseiensis Zone [20,24], similar to what is documented from the Peikangchi section of the Kuohsing area ( $F$ in Figure 1) [25,26], while the underlying Mushan Formation contains benthic foraminifers of Gaudryina hayasakai Zone. Typical late Oligocene species of planktic foraminifers Globigerina ciperoensis and G. angulisuturalis (Zones N2-N4), benthic foraminifers of Gaudryina hayasakai Zone and calcareous nannoplanktons of Zone NP 25 are recovered in the Wuchihshan Formation [24-27]. Comparing with the stratotype of the Wuchihshan Formation in northern Taiwan (836 m thick; Zones NP24-25) [26], only the uppermost part of this formation (no more than $200 \mathrm{~m}$ thick; 


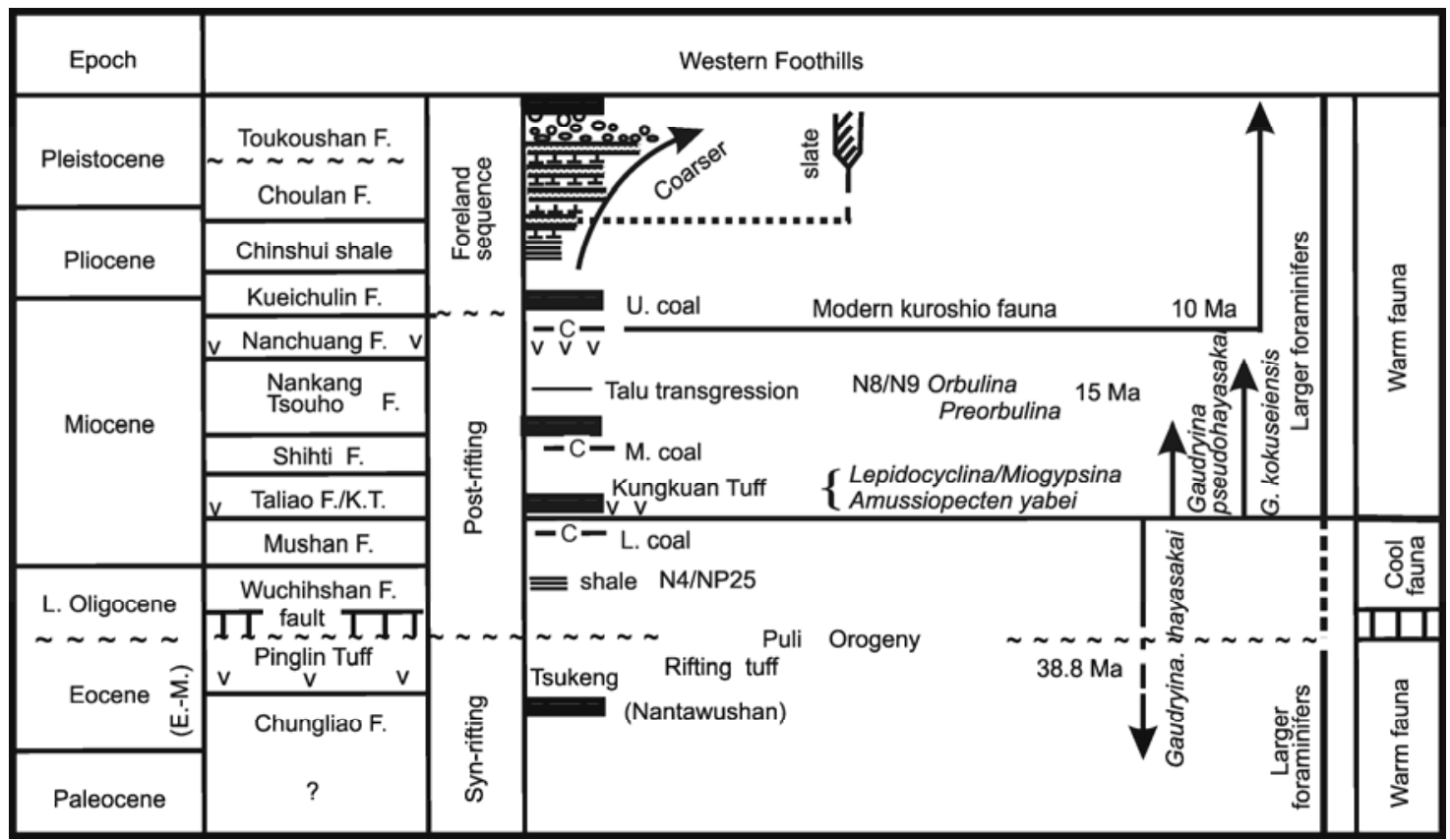

Figure 4 Cenozoic stratigraphy, stratigraphic distributions of main fauna (including indices of benthic foraminifer Gaudryina lineages) and key beds in the Western Foothills, northern Taiwan. v: tuff.
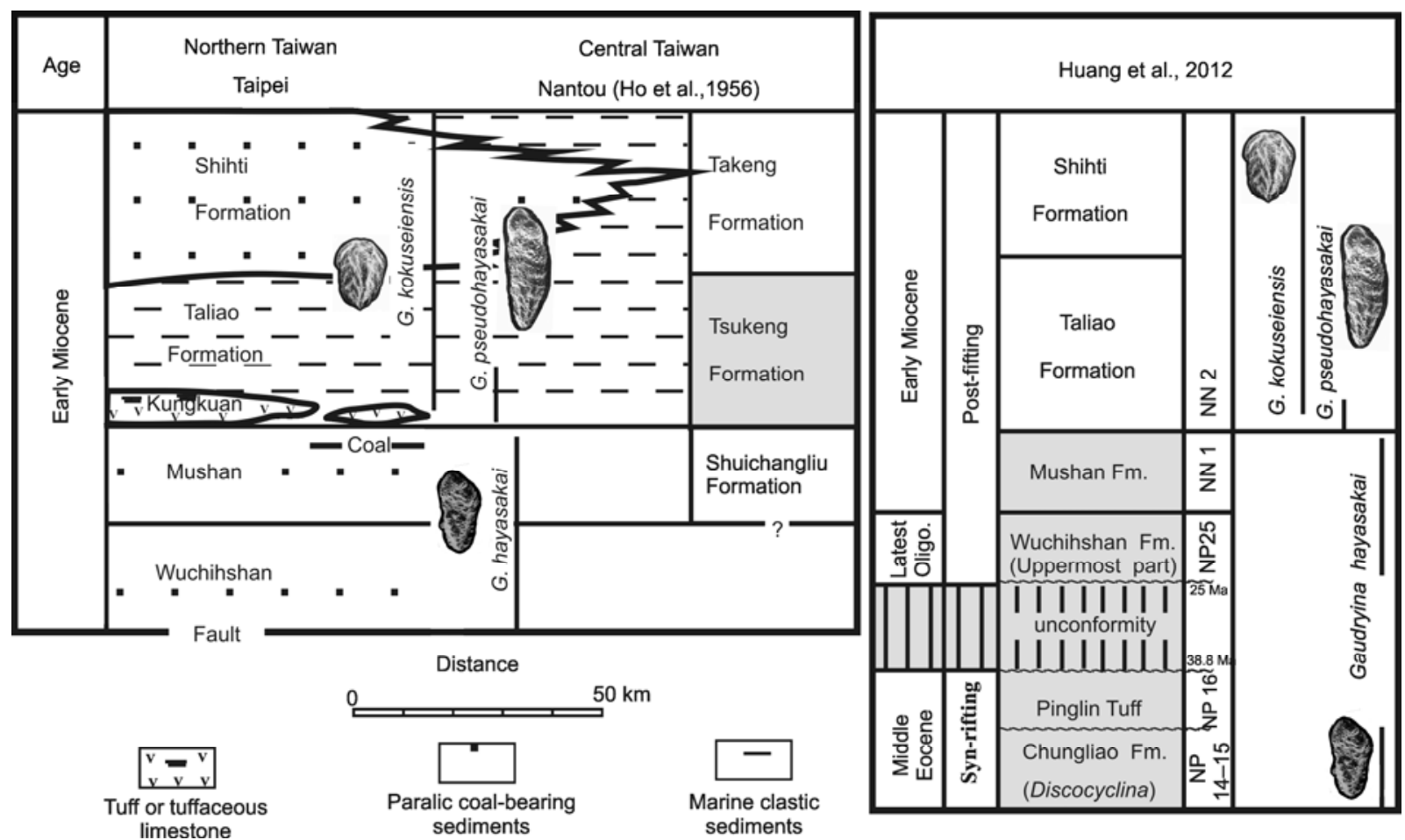

Figure 5 Stratigraphy exposed in the Tsukeng anticline structure near Nantou, central Taiwan. Based on detailed micropaleontological study on stratigraphic distributions of Gaudryina evolution lineages and calcareous nannoplanktons, the previously named Miocene "Tsukeng Formation" [22,23] (left panel, in gray color) is revised to include three independent lithostratigraphic units of (right panel, in gray color), in ascending order, the Middle Eocene Chungliao Formation and Pinglin Tuff of syn-rifting strata and the Latest Oligocene Wuchihshan Formation of post-rifting sequence [20,21].

Zone NP 25) is exposed in the Tsukeng anticline structure. It is unconformably overlying the Middle Eocene Pinglin Tuff. Zircon grains separated from the top of the Pinglin Tuff is currently dated as $38.8 \pm 1 \mathrm{Ma}$ (Late Middle Eocene) by LA-ICPMS consistent with its calcareous nannofossil age of Zone NP16 [20]. The Pinglin Tuff is paraconformably underlain by the Chungliao Formation which contains indigenous Middle Eocene larger foraminifers Discocyclina 
dispansa ex. interc. sella- dispansa and calcareous nannoplanktons of Zones NP 14-15 [21] (Figure 5). The Latest Oligocene Wuchihshan Formation (the uppermost part; NP 25 ; $25 \mathrm{Ma}$ ) and overlying units represent a post-rifting sequence, while the Middle Eocene Pinglin Tuff and the Chungliao Formation mark syn-rifting sequences deposited in the Nantou Basin. Between them there is the break-up unconformity with a missing $\sim 14$ my stratigraphic record between 25 and $39 \mathrm{Ma}$ (Figure 5).

\subsection{Stratigraphy of the Hsúehshan Range}

The Hsüehshan Range is located between the Western Foothills to the west and the Central Range to the east (Figure 1). It is primarily composed of argillite, slate and sandstone. In northern Taiwan, strata in the Hsüehshan Range, from top to bottom, are the Earliest Miocene Mushan Formation and the late Oligocene Tatungshan Formation, Tsuku Formation and Kankou Formation in the upper part (Upper Wulai Group), and the Szeleng Sandstone and Hsitsun Formation in the lower part (Lower Wulai Group; Figure 6). However, approaching the basement high area, for example in the Nantou area of central Taiwan, sedimentation rates become only $1 / 2-1 / 3$ of that in northern Taiwan [27]. Therefore, the standard stratigraphy used in northern Taiwan can no longer be appropriately applied in central Taiwan. Another stratigraphic scheme is thus proposed in ascending order: the earliest Miocene Mushan Formation, Late Oligocene Shuichangliu Formation (equivalent to the Upper Wulai Group) and the Paileng Formation (equivalent to the Lower Wulai Group; Figure 6). Before 1980, there was a general consensus [28], but without any paleontolog- ical evidence, that: (1) The Eocene-Oligocene strata are continuous deposition and the Late Oligocene Upper Wulai Group is conformably overlying the Eocene-Early Oligocene Lower Wulai Group whatever in northern or southern parts of the Hsúehshan Range, and (2) the age of the Szeleng Sandstone or the Paileng Formation straddles over the Eocene/Oligocene boundary (Figure 6, left).The Upper Wulai Group is composed of argillite and siltstone with abundant shallow-marine fossils [29,30]. In contrast, the Szeleng Sandstone or the Paileng Formation of the Lower Wulai Group is predominated by conglomerate, sandstone and siltstone with rich plant remains, revealing a braided river-lacustrine depositional environment (Figure 6; Figures S1, S2). Planar beddings are commonly observed in the Upper Wulai Group, suggesting deposition in a relative low energy regime. In contrast, large-scale cross beddings are frequently found in the Szeleng Sandstone or the Paileng Formation, showing sedimentation in a high energy regime (Figure 6; Figure S2). Multiple evidence of lithology, fossil content and sedimentary structure all point that depositional environments between the Upper and Lower Wulai Groups are very different (Figure 6).

Upper Wulai Group. The Upper Wulai Group is continuously deposited on the Asian continental shelf. It contains abundant Late Oligocene-Earliest Miocene Shihtsaoan shelf fauna belonging to the planktic foraminifers of Zone P20 (=Zone N1) N4 [24,28], benthic foraminifers Gaudryina hayasakai Zone [29] and calcareous nannoplanktons of Zones NP 23 -NN1 [30] (Figure 6).

Szeleng Sandston. In the stratotype along the NorthernCross-island Highway (E in Figure 1), the Szeleng Sandstone is composed of three parts [31,32] (Figure S1(e)): (1)

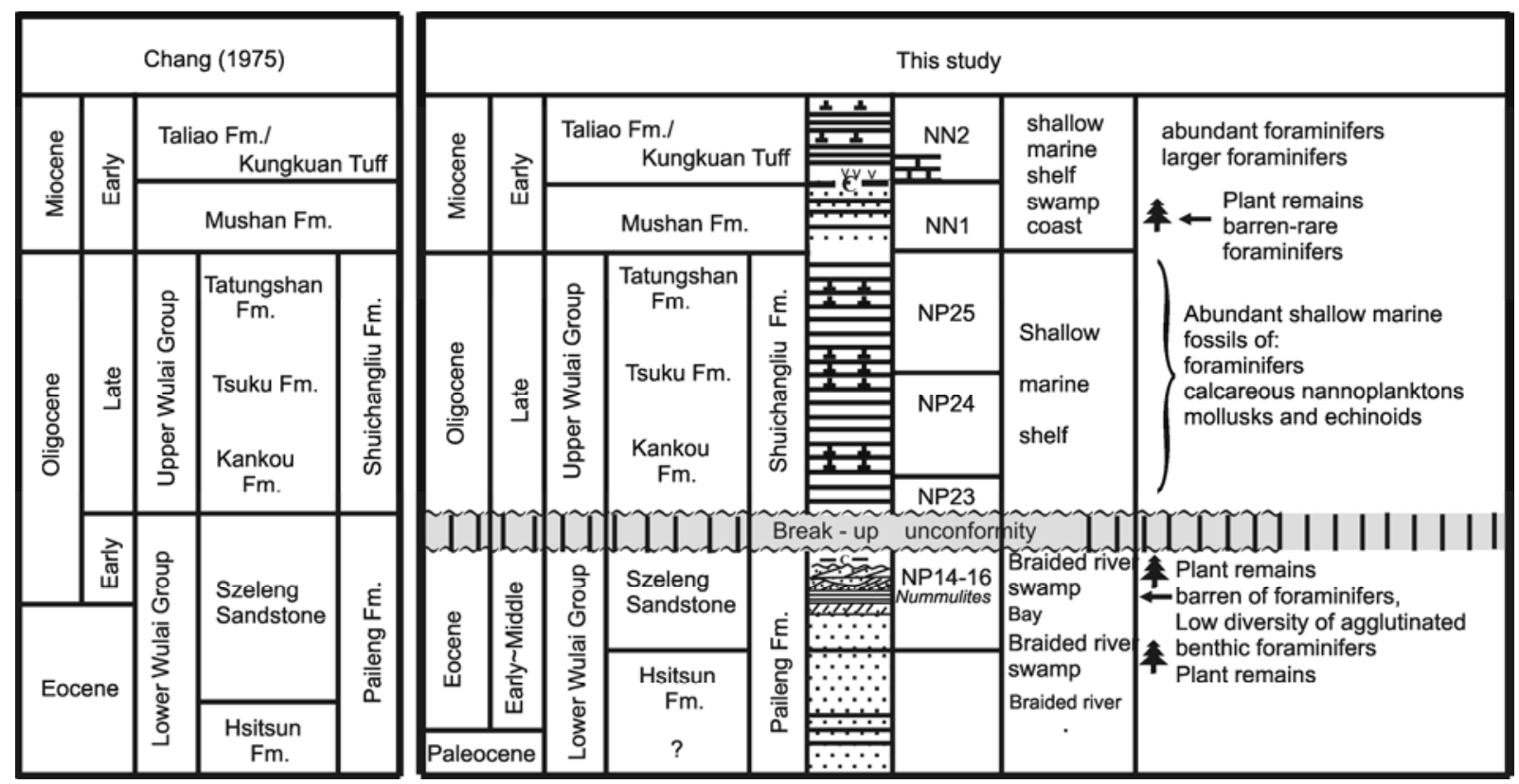

Figure 6 Stratigraphy of the Hsüehshan Range in northern Taiwan. Left: Previously proposed conformable model between the Upper and Lower Wulai Groups [28]. Right: Results of current study show a break-up unconformity between the Upper and Lower Wulai Groups. 
cross-bedded thick conglomerate-fine grained sandstone intercalated with ripple-flaser siltstone, coaly shale and several coal seams (each $2-5 \mathrm{~cm}$ thick) in the upper part ( 270 $\mathrm{m}$ thick), (2) thick shale ( $100 \mathrm{~m}$ in thickness) in the middle part, and (3) thick conglomerate, coarse-medium grained sandstone, flaser siltstone and black coaly shale $(\sim 635 \mathrm{~m}$ thick) in the lower part [31] (Figure 6).

In the upper and low parts of the Szeleng Sandstone there are abundant leaves and root remains of plants in the black coaly shale in which foraminifers are barren or very rare (Figure 6; Figures S1 and S2). Cross-bedding and small channel structures are common in the thick conglomerate and sandstone beds (Figure S2). Lithology, sedimentary structures and fossil content all point that the upper and lower parts of the Szeleng Sandstone represent lacustrine deposits accumulated in braided river-swamp environments (Figures 6 and 7). In comparison, the middle part (100 m thick) is high-organic content shale with rather abundant but low diversity benthic foraminifers predominated by agglutinated species ( $~ 95 \%$ of total specimens) of Cyclammina pacifica Beck, Cyclammina tani Ishizaki, Bathysiphon eocenicus Cushman and Hana, Martinottiella communis (d'Orbigny), Gaudryina hayasakai Chang, and Cribrostomoides sp., with little calcareous species (Figure S3), suggesting embayments with restricted circulation (Figure 6). Fresh water pelecypod Corbicula [33] has been documented from the upper parts of the Szeleng Sandstone exposed along the Pei-I Highway ( $\mathrm{C}$ in Figure 1), northern Taiwan, and of the Paileng Formation along the Kuohsing Peikangchi section ( $\mathrm{F}$ in Figure 1) in central Taiwan, consistent with occurrences of plant remains and lack of marine fauna in both formations.

In addition to the Northern-Cross-Island Highway section, larger scale cross-bedding structures are frequently observed in the conglomerate beds (each pebble $1-3 \mathrm{~cm}$ in diameter) of the Szeleng Sandstone in the Lungtung Cap section (D in Figure 1) and the Paileng Formation exposed along the Kuohsing Peikangchi section ( $F$ in Figure 1) of central Taiwan [31,32] (Figure S2). Except limited agglutinated benthic foraminifers Cyclammina pacifica Beck and Bathysiphon eocenicus Cushman \& Hanna, marine fossils are almost barren in the upper part of the Szeleng Sandstone in the northern Hsüehshan Range [31,32,34] (for example: Nanshihchi section, Peishihchi section, Pei-I Highway section, Lungtung Cap section; Figure S1) in northern Taiwan and the Paileng Formation in the Kuohsing Peikangchi section, central Taiwan. However, a single larger foraminifera Nummulites sp. (Figure 7(b)) companied by fragments of pelecypods is found in a $8 \mathrm{~cm}$-thick calcareous fossil-bearing sandstone, which is supposedly a condense Nummulitesbearing bed [34] in a drilling core of the Nanshihchi section ((b) in Figure S1). Unfortunately, most calcareous fossils are almost completely dissolved (Figure 7 (b)).

A 500-m long core (Figure 7(c), PH-29-1) drilling into the upper part of the Szeleng Sandstone exposed along the
Pei-I Highway, near Shih-Pei (C in Figure 1), shows a sequence of thick conglomerate to medium and fine-grained sandstone with coaly siltstone. Plant remains are commonly found, while very limited brackish benthic foraminifers Trochammina inflata (Montagu) are recovered in back coaly siltstones, indicating braided river and swamp environments [32]. However, there are several calcareous fine sandstone beds with condensed Nummulites junbarensis Matsumaru [32,35] (Figure 7(c)). N. junbarensis belonging to N. exilis group is reported from the Early-Middle Eocene Akashimisaki Formation (calcareous nannoplanktic Zone NP14) [36] of the Kyushu Island, Japan, and the Paileng Formation in southern part of the Hsúehshan Range, central Taiwan [37]. Similar larger foraminifers Assilina [38] with calcareous nannoplanktons of Zones NP14-15 are documented from the Paileng Formation in Jun-Keng section, central Taiwan [39] (G in Figure 1).

In a very unusual coaly siltstone bed (less than $20 \mathrm{~cm}$ thick; sample NH-102, Figure S1(e)) in the uppermost part o the Szeleng Sandstone along the Northern-Cross-IslandHighway section (Figure S1(e)) contains very rich foraminifers [31,32] (Figure S2(a)). Unfortunately all of calcareous tests of foraminifers are totally dissolved, therefore without calcareous nannofossil preserved, only clay molds remained [31,32] (Figure S2(a)). However, based on some fundamental morphological characters, like test size, chamber arrangement, position and number of aperture, chamber number of the last whorl, it is still possible to identify their taxonomy or to cluster them into a group of some planktic foraminifers, including: the species restricted in Middle Eocene [40,41] of Orbulinoides (?) (Last Appearance Datum, LAD: $40.1 \mathrm{Ma}$, Zone P13), Turborotalia frontosa (Subbotina) ? (LAD: $39.3 \mathrm{Ma}$ ), Subbotina linaperta (Finlay) (LAD: $37.7 \mathrm{Ma}$ ); species extending from Middle Eocene to Oligocene: Turborotalia cerroazulensis (Cole) (LAD: 33.8 Ma), Pseudohastigerina spp.(LAD: $32.0 \mathrm{Ma})$, Turborotalia ampliapertura (LAD: $30.3 \mathrm{Ma}$ ), Chiloguembelina sp. (LAD: 28.5 Ma), Catapsydrax unicavus Bolli, Loeblich and Tappan, Subbotina crociapertura Blow, Subbotina yeguaensis (Weinzierl and Applin), Globigerinatheka (?) spp., and Dentoglobigerina galavisi-pseudovenezuelana group. Oligocene indices of planktic foraminifers, for examples Globigerina ciperoensis and $G$. angulisuturalis which were commonly occurred in the Upper Wulai Group, are never found in this 20-cm-thick siltstone of the Szeleng Sandstone.

Integrating positive evidence of (1) Nummulites junbarensis in the Szeleng Sandstone (Pei-I Highway section, core PH-29-1) and in the Paileng Formation, (2) Nummulites sp. in the Szeleng Sandstone of the Nanshichi section, (3) Assilina formosensis associated with calcareous nannofossils of Zones NP14-15 in the Paileng Formation of the Jun-Keng section, and (4) Eocene planktic foraminifers in the upper part of the stratotype Szeleng Sandstone (sample NH-102), the Szeleng Sandstone or Paileng Formation can only be assigned to Middle Eocene in age (Figure 6). 


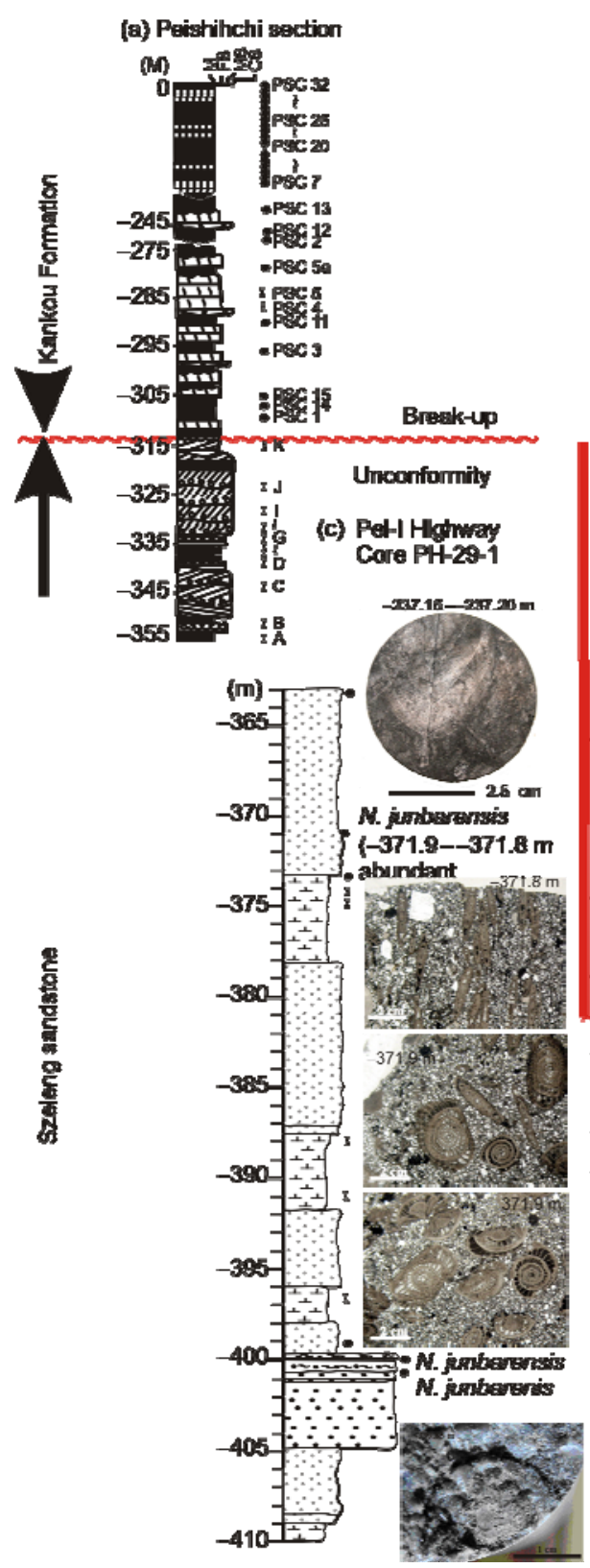

(b) Nareshihchi section

(m)
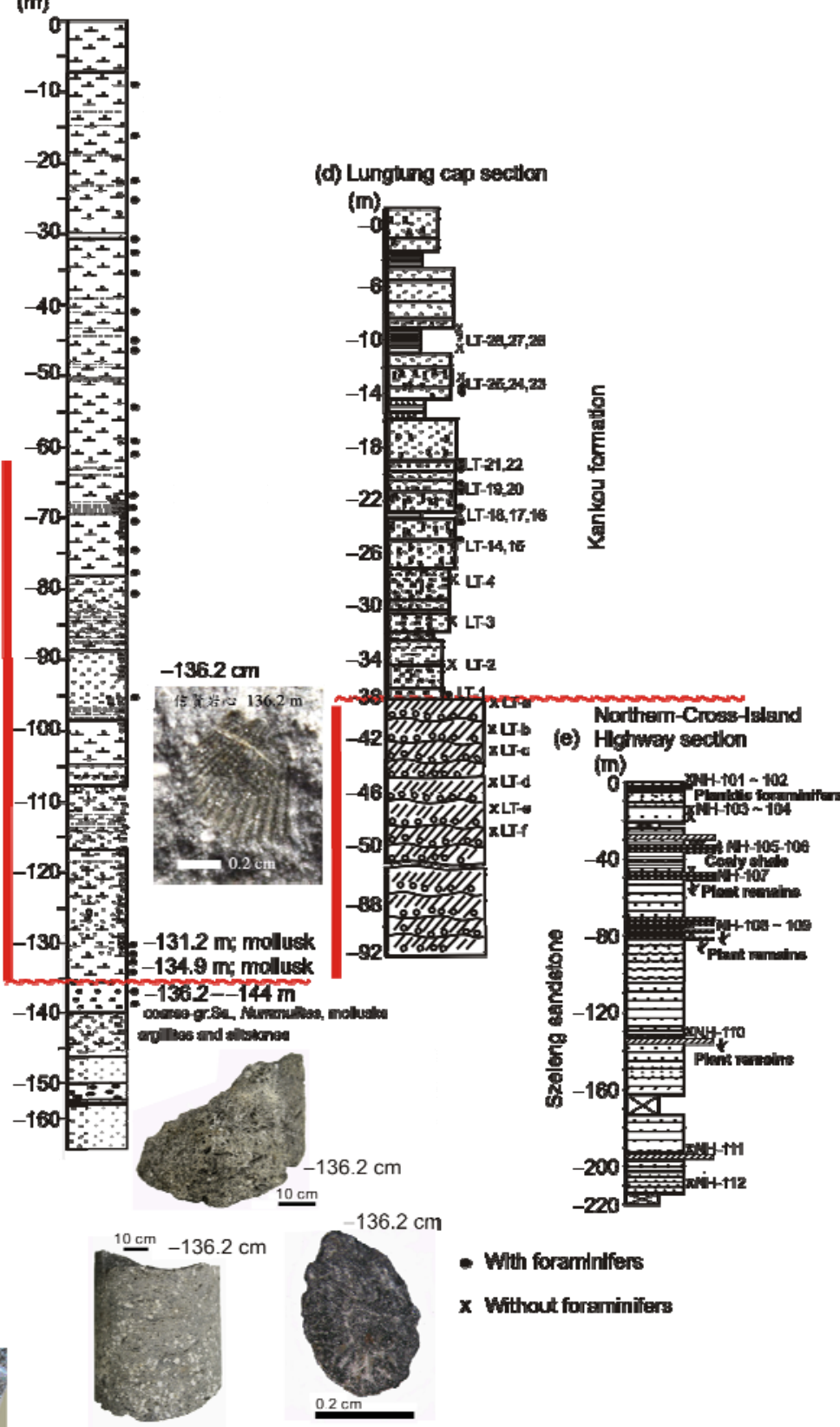

Figure 7 Correlation of five study sections in northern Hsüehshan Range showing contrasting lithology, sedimentary structures and fauna in the lower part of the Kankou Formation (Upper Wulai Group) and the upper part of the Szeleng Sandstone (Lower Wulai Group). •, Sample with foraminifers; X, sample without foraminifers. Wavy line marks the break-up unconformity between the Upper and Lower Wulai Groups.

\subsection{Stratigraphy in the Southern-Cross-Island Highway section}

The Southern-Cross-Island Highway section (L in Figure 1) exposes Miocene to Paleozoic (?)- Mesozoic sequences in the southern part of the Central Range (Figure 8). These sequences include four lithostratigraphic units of Middle Miocene Meishan Formation, Late Oligocene-Early Miocene Likuan Formation, Middle Eocene Kueiku Formation [42,43] (Figure 8) and Paleozoic (?)-Mesozoic Tainanao
Group. The Lushanian Meishan Formation (siltstone and slate) was deposited on continental slope in the Middle Miocene (calcareous nannoplankton Zones NN4-7) [43,44]. The Latest Oligocene-Early Miocene Likuan Formation is predominantly of fine sandstone with subordinate shale-slate with calcareous nannofossils of Zones NN2-3 [44]. In addition there is a thin limestone ( $\sim 5 \mathrm{~m}$ thick) with larger foraminifers Eulepidina-Lepidocyclina-Operculina-Heterosteginareticulated Nummulites of the Letter Stage Td [45] occur as 
(a)

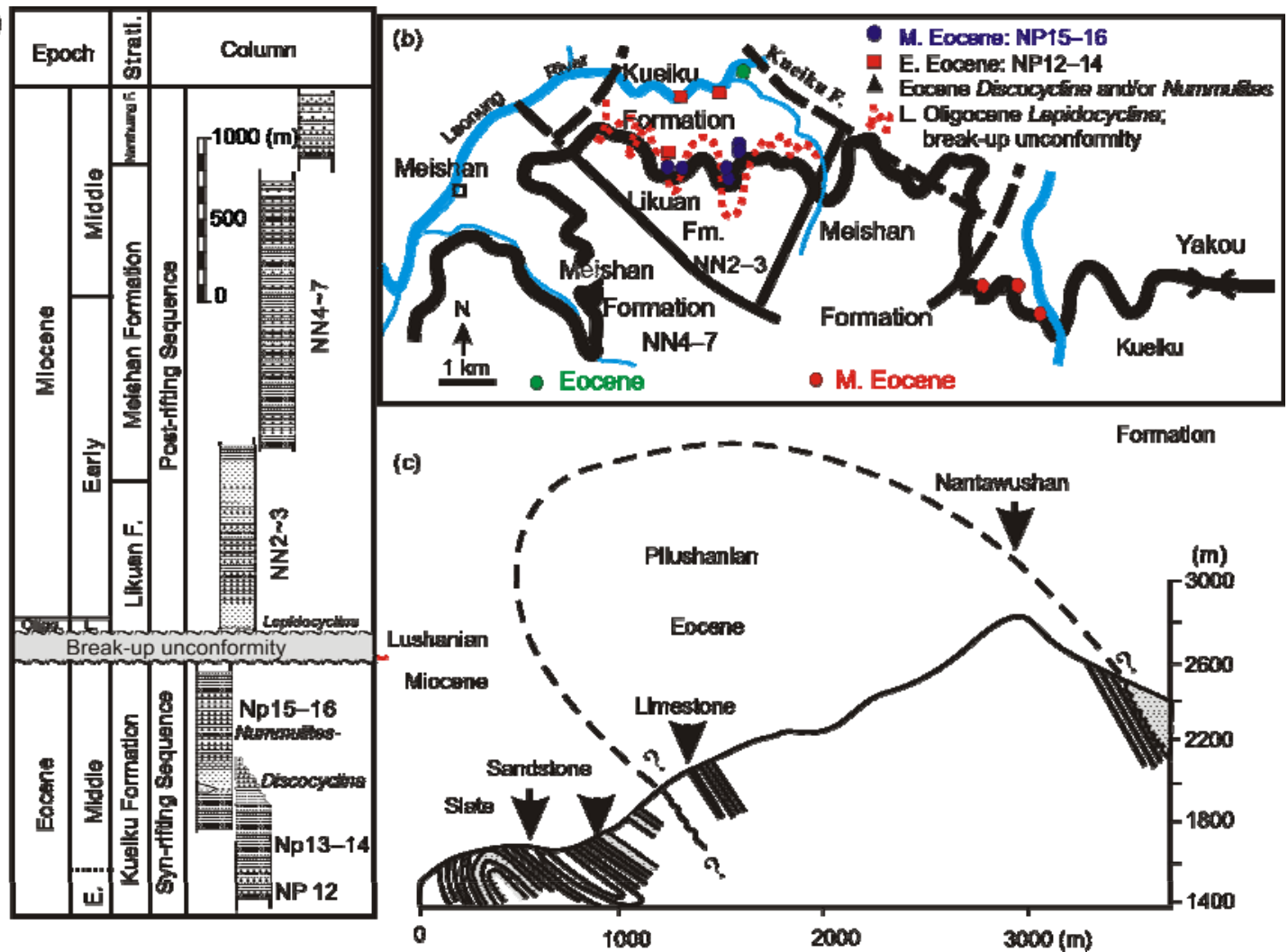

Figure 8 (a) Stratigraphy and (b) geological map along the Southern-Cross-Island Highway section with sample locations of calcareous nannoplanktons [44]; (c) Cross section over the Nantawushan in the southern Central Range [46] (N in Figure 1), showing a break-up unconformity between the Middle Eocene and Latest Oligocene-Miocene formations in the accretionary prism of the southern Central Range.

the base of this formation. This Latest Oligocene limestone is unconformably overlying the Early-Middle Eocene Kueiku Formation [42]. The latter (meta-sandstone, limestone, and slate) contains Eocene Pilushanian fauna [28] of larger foraminifers Nummulites-Discocyclina and calcareous nannoplanktons of Zones NP12-16 [44]. There are also synrifting volcanics in the Kueiku Formation unconformably overlying the Late Paleozoic (?)-Mesozoic Tainanao Group [28] of metamorphic schist, phyllite and marble. The Middle Miocene Meishan Formation and the Latest OligoceneMiddle Miocene Likuan Formation represent the post-rifting strata deposited on the continental slope of the northeastern SCS before they were accreted into the accretionary prism in late Miocene. The Early-Middle Eocene Kueiku Formation marks the syn-rifting sequence correlated with the Pinglin Tuff-Chungliao Formation in the Western Foothills or the Lower Wulai Group in the Hsüehshan Range (Figure 8). Accordingly, there is the break-up unconformity between the Latest Oligocene-Early Miocene Likuan Formation and the Early-Middle Eocene Kueiku Formation (Figure 8). The Late Paleozoic(?)-Mesozoic Tainanao Group is the pre-rifting basement on which develops the Paleogene rifting basin. Consequently, there is the pre-rifting unconformity between the Eocene Kueiku Formation and the underlying Paleozoic (?)-Mesozoic Tainanao Group (Figure 8). In this context, the Southern-Cross-Island Highway section is the best geo- logical window looking into the Mesozoic-Cenozoic stratigraphy of the northern SCS and the Taiwan Strait (Figure 2).

\subsection{Time of break-up unconformity recorded in Taiwan region}

Intensive stratigraphic study on the Taiwan Cenozoic sequences reveals that there is a regional break-up unconformity between the Middle Eocene strata and the late Oligocene sequences throughout Taiwan mountain belts. The break-up unconformity (33-39 Ma) occurred between Zones N1 and P13 of planktic foraminiferal stratigraphy or between Zones NP23 and NP16 of calcareous nannoplantons (Figure 9). Late Eocene and Earliest Oligocene strata are always missing not only in drillings offshore the Taiwan Strait, but also in exposures of the Taiwan orogenic belt. The duration or age gap of the unconformity may vary in different places: longer gap is found in horst regions like the Peikang Basement High (Well PK-3 in Figure 9) and the Nantawushan region [46] in the southern Central Range, but shorter gap exists in basin center like the Penghu Basin in the Taiwan Strait or the Nantou Basin in the Western Foothills (Figure 9). The break-up unconformity is associated with the Puli Orogeny [47] correlative to $\mathrm{T}_{7}$ unconformity (Nanhai Orogeny) in the PRMB [48] of the northern SCS. This regional break-up unconformity leads to formations of 


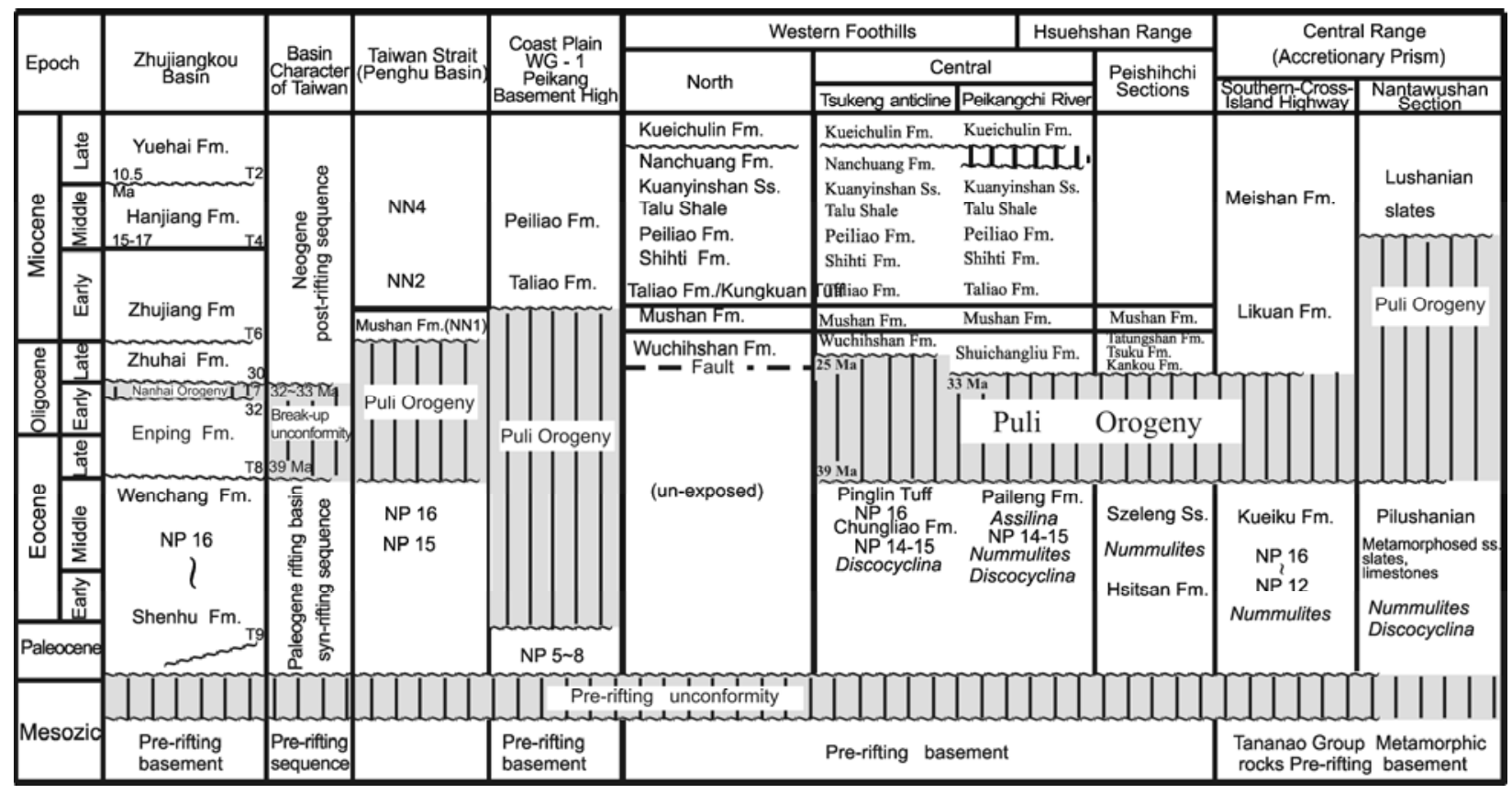

Figure 9 Correlation of break-up unconformity (Puli Orogeny) in various sections of the Taiwan mountain belt. The break-up unconformity in Taiwan is correlated with the $\mathrm{T}_{7}$ unconformity (Nanhai Orogeny) in the PRMB [48] of the northern SCS.

Paleogene rifting basins on continental crust and ultimately an opening of the SCS oceanic crust. These relationships suggest that the incipient formation age of the SCS oceanic crust could be between 33 and 39 Ma.

\section{Strata missing and slumping near Oligocene/ Miocene boundary in the SCS deep basin and its response in Taiwan shallow shelf sequences}

\subsection{Present study in SCS}

Stratigraphic and sedimentological studies on ODP 1148 deep-sea core show occurrence of a stratigraphic gap or hiatus associated with slumping features near the Oligocene/ Miocene boundary (27.5-23 Ma) [10,11]. This gap is also shown by an occurrence of the so-called "Double refractors" in seismic profile $[10,11]$. Lithology also changes significantly from hemi-pelagics in Late Oligocene upward to a mixing of chalk with hemi-pelagics. Sedimentation rate also decreases upward toward the Oligocene/Miocene boundary. Slumping features associated with missing strata in this special time interval $[10,12]$ were interpreted to be resulted from a jumping of the MOR at $\mathrm{C}_{7}$ Chron ( 25 Ma) $[42,49]$.

\subsection{Taiwan Oligocene/Miocene stratigraphy}

Late Oligocene and Early Miocene strata in the Western Foothills and the Hsüehshan Range (Figures 1 and 2) are deposited in the passive Asian continental shelf on which sedimentation is generally controlled by fluctuations of glob- al sea level. The late Oligocene Wuchihshan Formation and the Earliest Miocene Mushan Formation are well exposed in their stratotype section along the Waiwulun coast $(\mathrm{H}$ in Figure 1), northern Taiwan. The stratigraphy of both formations has been well studied. Along the Waiwulun coastal section, the Wuchihshan Formation (836 m thick) is composed predominantly of amalgamated storm sandstone beds and alternations of siltstone and shale, which are intensively bioturbated by Thalasinoides-Ophiomorpha ichnofossils and contain shallow marine mollusks, benthic foraminifers of Gaudryina hayasakai Zone [50], rare planktic foraminifers of Zones N2-N4 [24] and calcareous nannofossils of Zones NP24-25 [51]. In addition, the Latest OligoceneEarliest Miocene indices of planktic foraminifers Globigerinoides primordius (Zone N4) and Latest Oligocene calcareous nannoplanktons of Zone NP25 are documented in its uppermost 70-m-thick shale [24,26,51] (Figure 4).

The Mushan Formation (650 m thick) is also composed predominantly of thick amalgamated storm sandstone beds with subordinate siltstone, coaly shale and three coal seams (each $<20 \mathrm{~cm}$ thick) in the uppermost part. Marine fossils are very rare or even absent in most parts of the Mushan Formation. The Mushan Formation is conformably overlain by the Early Miocene marine unit of the Taliao Formation/ Kungkuan Tuff with planktic foraminifers of Zone N5 [52] and calcareous nannoplanktons of Zone NN2 [51] (Figure 4) that marks the transgression equivalent to 1.4 of TB1 Supercycle [53]. The Kungkuan Tuff is a lenticular calcareous tuff unit (0-200 m thick) bearing Early Miocene indices of larger foraminiferal Genera Miogypsinoides, Miogypsina and Lepidocyclina [28], smaller benthic foraminifers Gaudryina 
pseudohayasakai Chang and Gaudryina kokuseiensis Ishiza$\mathrm{ki}$, and mollusk of Amussiopecten yabei (Nomura) (Figure 4). The Taliao Formation is intensively bioturbated fine sandstone-siltstone-shale with fauna belonging to benthic foraminiferal Gaudryina pseudo-hayasakai Zone and Gaudryina kokuseiensis Zone similar to what are found in the Kungkuan Tuff [52], but quite different from fauna of the Gaudryina hayasakai Zone in the underlying Mushan and Wuchihshan Formations [50] (Figure 4). Although planktic fossils are barren in the Mushan Formation, based on fauna in the underlying Wuchihshan Formation (top N4 or NP 25) and the overlying Taliao Formation/Kungkuan Tuff (N5 or NN2), it is convincible that the Mushan Formation was deposited in planktic foraminiferal Zone N4 or Zone NN1 of calcareous nannoplanktons [54] of Earliest Miocene in age.

There are different stratigraphic names assigned for the Late Oligocene sequences in northern Taiwan (Wuchihshan Formation in Western Foothills, the Tatungshan, Tsuku and Kankou Formations in the northern Hsúehshan Range, or the Shuichangliu Formation in the southern Hsúehshan Range). The Shuichangliu Formation ( $750 \mathrm{~m}$ thick) is primarily composed of thick shale or argillite with subordinate thin fine sandstone or siltstone (each bed 1-5 cm thick). Like the Wuchihshan Formation, the Shuichangliu Formation also contains rich shallow marine fossils of benthic foraminifers of Gaudryina hayasakai Zone, planktic foraminifers of Zones N1-N4 [25] and calcareous nannofossils of Zones NP23-25 [27]. The Mushan Formation (150 m thick, equivalent to the former name of the Shihszeku Formation [22,24,27]), is conformably overlying the Shuichangliu Formation [24,27]. Except no coal seam, lithology and fauna (Gaudryina hayasakai Zone) of the Mushan Formation in central Taiwan are comparable to its stratotype in northern Taiwan. Although planktic foraminifers are rare in the Mushan Formation, based on indices of Zone N4 (or NP25) appear in the upper part of the Shuichangliu Formation and Zone N5 (or NN2) in the overlying Taliao Formation (=Tanliaoti Formation [22,24,27]), the depositional age of the Mushan Formation in central Taiwan can be assigned to Zone N4/N5 transition of planktic foraminifers [25] or within NN1 of calcareous nannoplanktons [27] like its stratotype in northern Taiwan.

Accordingly, neither stratigraphic gap nor slumping features are found within the stratigraphic interval of planktic foraminiferal Zones N2-N5 or Zones NP24-NN2 between the Wuchihshan Formation and the Taliao Formations $(\sim 1900 \mathrm{~m}$ thick in total) in the northern Taiwan or between the Shuichangliu Formation and Taliao Formation $(\sim 1000$ $\mathrm{m}$ in total) in central Taiwan. There only exists a change of sedimentation shallowing upward from an inner shelf in the Late Oligocene (Zones N2-3 or Zones NP 24-25) to a swamp-coast environment in the Earliest Miocene (Top Zone N4 or Zone NN1) followed by a transgressive shallow shelf deposition in the Early Miocene (Zone N5 or Zone NN2). Therefore, the stratigraphic gap and slumping fea- tures that are recorded in the ODP 1148 deep sea core, are not find in the coeval time interval of shallow shelf sequences in Taiwan. But, there is a faunal change event near the Oligocene/Miocene boundary of Taiwan presumably due to paleoclimate fluctuations [50]. For example, warm water indices of larger foraminifers are not found in the Late Oligocene strata, but are commonly observed in the Early Miocene Taliao Formation/Kungkuan Tuff and the younger formations (Figure 4). This indicates that paleoclimate might have changed from a cool condition in late Oligocene-Earliest Miocene time (Zones N1-4 or NP 23-25) without larger foraminifers in the Wuchihshan-Mushan Formations to a warm climate in the Early Miocene Taliao Formation/ Kungkuan Tuff with larger foraminifers (Figure 4).

\section{Middle-Late Miocene sedimentation and faunal turnover in Taiwan Western Foothill in response to paleoceanograpic re-organization in SCS deep basin}

The ODP Site 1148 deep sea core represents one of the most complete records with high resolution of the Miocene oxygen and carbon isotope stratigraphy of benthic foraminifers Cibicidoides wuellerstorfi in the West Pacific [13,14] (Figure 8). One of the most characteristics of Core 1148 is a three-step-wise positive shift of benthic foraminiferal oxygen isotope stratigraphy in the following time intervals: (I) Early to Middle Miocene (24-14 Ma), (II) Middle Miocene to Early Pliocene (14-4 Ma) and (III) Early Pliocene to Present (4-0 Ma; Figure 10). These indicate a global cooling trend since the Early Miocene. In most time intervals of Steps (I) and (II), variations of oxygen isotope values are relative smooth, but highly fluctuate up to $0.9 \%$ in the transition from Step (I) to Step (II) (14.4-13.6 Ma) in response to a dramatic ice expansions in the Antarctic Ocean. This further leads to a global bottom water cooling and a global sea-level dropping [53,55,56] (Figure 10). In addition, oxygen isotopic values get the most negative and positive, respectively, in Middle Miocene (17.2-14.5 Ma) and Late Miocene (10.2-9.4 Ma), representing the Miocene climatic optimum and minimum time, respectively (Figure 10).

Although the Miocene deep-sea paleoceanography does not record in the Taiwan shallow shelf sequences, the oxygen isotope curve of benthic foraminifers is generally parallel to the planktic foraminiferal oxygen isotope curve $[14,15]$. This relationship indicates that both curves are fundamentally controlled by common mechanisms, for example global ice volume changes, which further controls fluctuations of global sea level, climate and eventually also sedimentation and faunal assemblages in shallow shelf sequences of Taiwan.

On the other hand, one of the most characteristic faunal changes in Miocene sequences of Taiwan occurred in Middle/ 


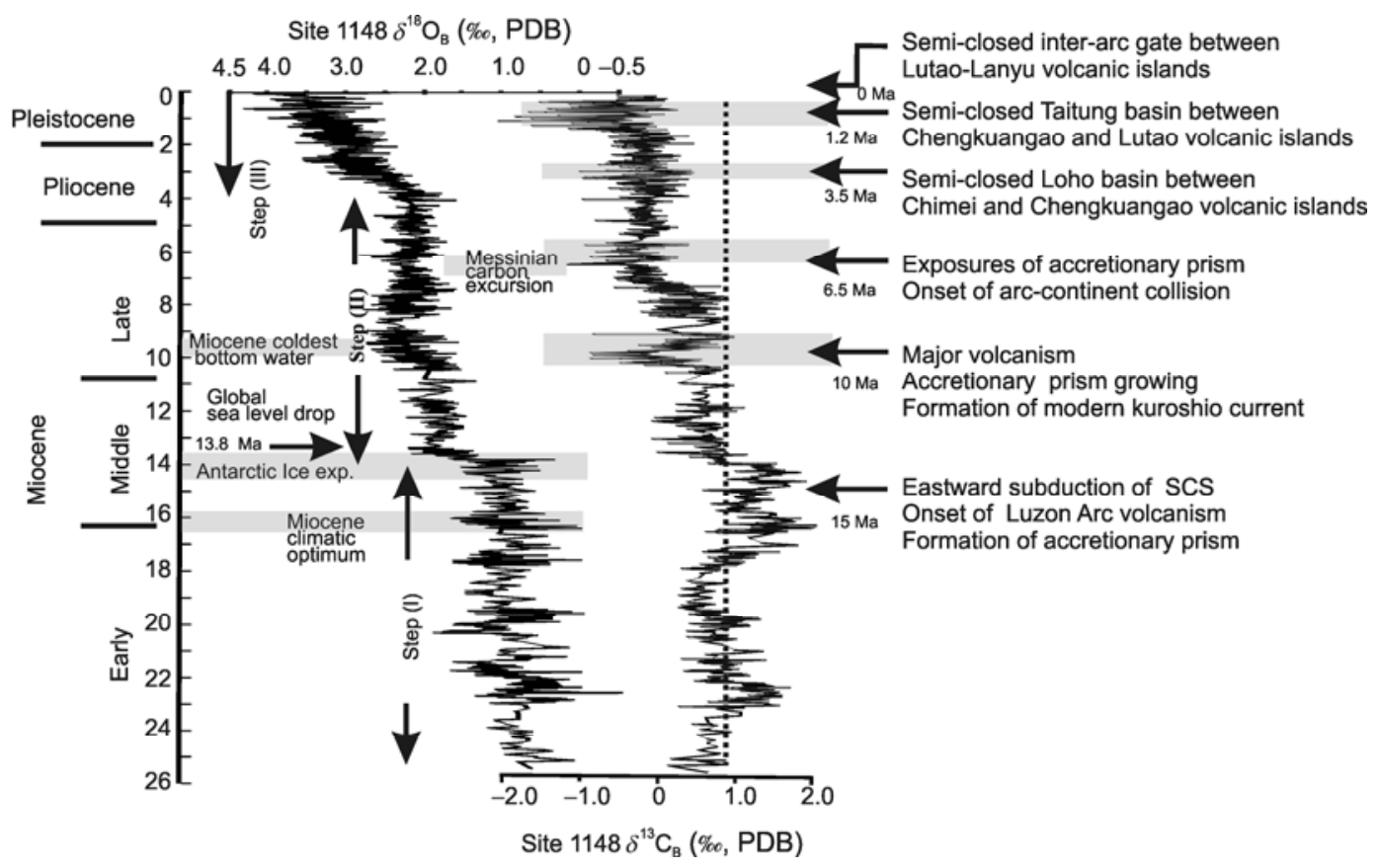

Figure 10 Miocene benthic foraminiferal oxygen and carbon isotope stratigraphy of ODP 1148 core [14,15], showing three-step-wise shifts of oxygen isotope values in the last $26 \mathrm{Ma}$. Right: Interpretations of the SCS negative shifts of carbon isotope stratigraphy linked to global signals and local Taiwan tectonics in the Hengchun Ridge-Hengchun Peninsula-Central Range accretionary prism and the Luzon Arc-Coastal Range.

Late Miocene transition [57] (Figure 11, Chuhuangkeng section near Miaoli as example, $\mathbf{J}$ in Figure 1), coeval to change of benthic foraminiferal oxygen isotope shifts from Step (I) to Step (II) in the ODP 1148 deep-sea core (15-10 Ma; Figure 11). The Taiwan sequence shows a shallowing sedimentation upsection from the Middle Miocene outer shelf-upper slope Talu Shale (Zones N8-9 during the Miocene Optimum and highest sea-level stand, 16-14.5 Ma; Figure 11), through shelf strata of the Kuanyinshan Sandstone (14.5-13.5 Ma) to coast dune sands and swamp environments of the coal-bearing Nanchung Formation (13.5-10 Ma; Figure 11) due to the Antarctic ice expansion (Figure 11). The regression in Middle/Late Miocene boundary further caused a subaerial exposure of the Late Middle Miocene sequence and a non-deposition of the Late Miocene Nanchung Formation on the Peikang Basement High area [25] (for example the Kuohsing Peikangchi section near Nantou, central Taiwan; F in Figure 1).

In addition, there is also a distinct faunal turnover event that occurred in the Middle/Late Miocene boundary of Taiwan sequences [57] (Figure 11). Not only abundance of benthic foraminifers decreases upward, faunal diversity in terms of species number also decreases upward from 40-20 species in the Talu Shale $(16-14.5 \mathrm{Ma})$, through $<10$ species in the Kuanyinshan Sandstone (14.5-13.5 Ma) to less than 2 species in the lower part of the Nanchuang Formation (13.5-12.9 Ma; Figure 11). Marine fossils are even totally barren in the middle part of the Nanchuang Formation (12.9-10.2 Ma) until the uppermost Nanchuang Formation (10.2 Ma) and the overlying Kueichulin Formation (Figure
11). The Early-Middle Miocene endemic benthic foraminifers, like Textularia kansaiensis Ishizaki, Textularia akaminei Ishizaki, Lenticulina taluensis Chang, Bigenerina shihtiensis Chang, Gaudryina kokuseiensis Ishizaki, Guttulina pacifica ishizakii Chang, are extinct in the Kuanyinshan Sandstone or the lowest part of the Nanchuang Formation. New benthic foraminifers, that are very different from the Early-Middle Miocene assemblage, appear from the uppermost part of the Nanchuang Formation when the next transgression started at 10.2 Ma. Benthic foraminifers of euryhaline species of Ammonia cf. japonica (Hada) and A. altispira Qin and Lin appear first, then the fauna living in a normal marine shelf, including Sigmoidella subtaiwanica Nakamura, Asterorotalia yabei (Ishizaki), A. inspinosa Huang, A. subtrispinosa (Nakamura), Pseudorotalia tikutoensis (Nakamura), P. schroeteriana (Parker and Jones), Bigenerina nodosaria d'Orbigny, B. taiwanica Nakamura, Textularia pseudokansaiensis Chang and T. alishanensis Chang (Figure 9). This faunal turnover event that the Early-Middle Miocene benthic foraminiferal assemblage was totally replaced by the new Late Miocene foraminiferal assemblage is known as the "Post-Taluan Faunal Break" or the "Post-Lushanian Faunal Change" in Taiwan [57,58]. Such a faunal turnover event is not simply caused by a paleobathymetric change alone, but due to a re-organization of paleoceanography because a similar change of depositional environments from an outer shelf-upper slope strata (lower part of Taliao Formation) upward through inner shelf (part part of Taliao Formation) and a coast deposition (Shihti Formation) to the following transgressive Tsouho 


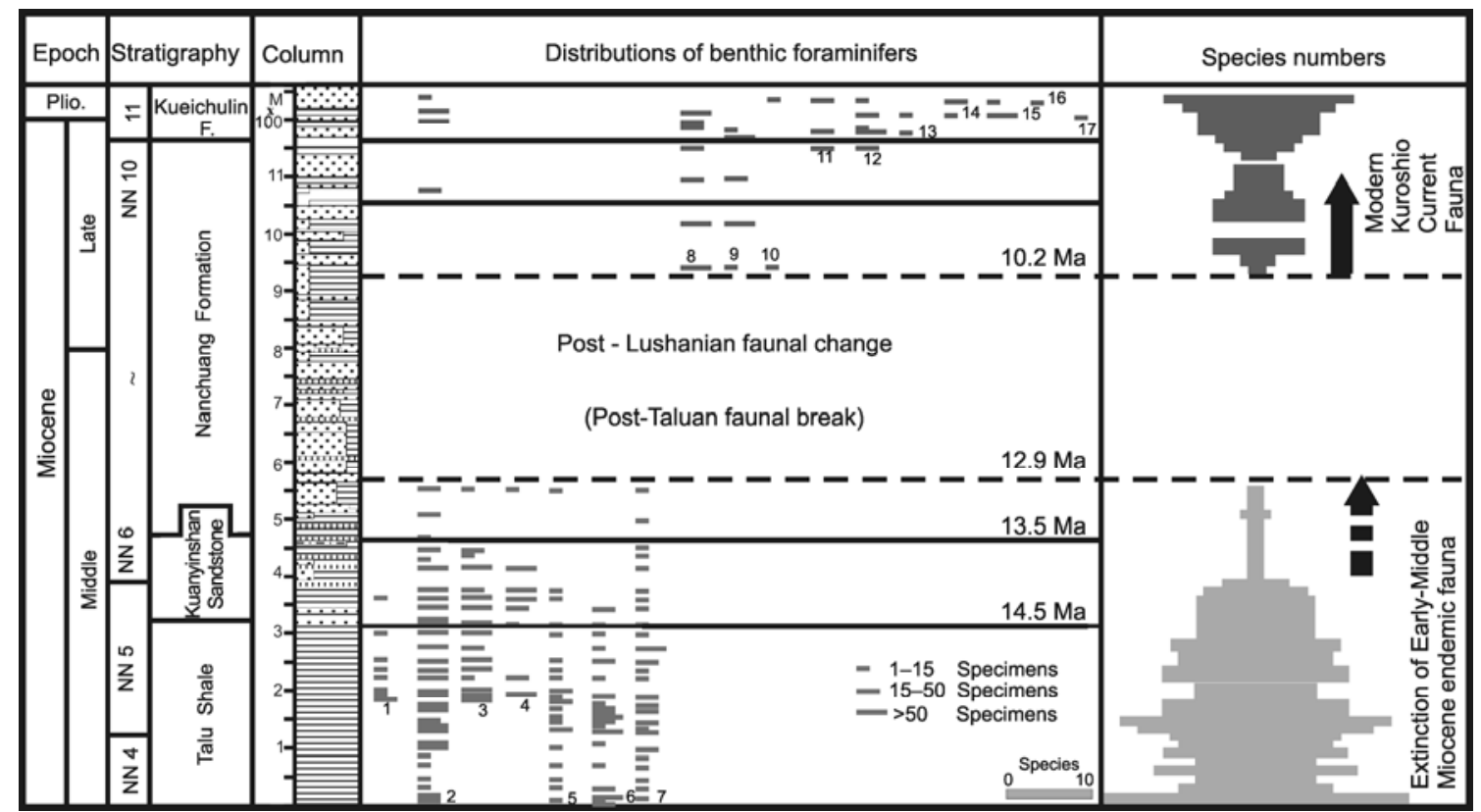

Figure 11 Faunal turnover event recorded in the Miocene sequence of the Miaoli Chuhangkeng section [57,58] (J in Figure 1), Western Foothill.1, Textularia kansaiensis Ishizaki; 2, Heterolepa praecincta (Karrer); 3, Tesxtularia akaminei Murata; 4, Uvigerina nitidula Schwager; 5, Guttulina ishizakii Chang; 6, Bigenerina shihtiensis Chang; 7, Ammonia sp1.; 8, A. cf. japonica (Hada); 9, Ammonia altispira Qin and Lin; 10, Sigmoidella subtaiwanica Nakamura; 11, Textularia pseudokansaiensis Chang; 12, Asterorotalia yabei (Ishizaki)+A. gaimardii (d'Orbigny); 13, Asterorotalia inspinosa Huang; 14, A. sp., 15, A. subtrispinosa (Nakamura); 16, Bigenerina nodosaria d'Orbigny; 17, Pseudorotalia tikutoensis (Nakamura).

Formation, has happened in Early to Middle Miocene, but the benthic foraminiferal assemblage did not change at all [58] (Figure 4).

The new occurrence of benthic foraminifers are identical to the modern fauna now living in the eastern Taiwan Strait, shelf-upper slope off southern Taiwan and the outer-shelf of the East China Sea where the Kuroshio Current flows northwestward through the shelf [59]. It is speculated that the occurrence of the new fauna after 10.2 Ma might represent an initiation of the modern Kuroshio Current by an intensification of the Western Boundary Current of the North Pacific [57] when the Indo-Pacific seaway began to close due to the subduction-collision between the Australia continent and the Indonesia Banda Arc in 12-8 Ma [57,60]. The occurrence of the modern Kuroshio Current benthic foraminiferal fauna at $10.2 \mathrm{Ma}$ is closely similar to an appearance of modern benthic foraminifers in ODP Site 289 at $9 \mathrm{Ma}$ in the Java Sea region [56]. Both events post-date global cooling when the Antarctic ice volume significantly expanded, suggesting a re-organization of paleoceanography in Middle/Late Miocene boundary in the West Pacific.

\section{Mechanism responsible for semi-closing SCS linked to Taiwan tectonics}

\subsection{Modern deep sea circulations in the semi-closed SCS}

The SCS deep basin water is sourced from the West Pacific Deep Water $(-1000$ to $-2500 \mathrm{~m})$ which flows westward through the Luzon Strait and then sinks downward to the SCS deep basin. Therefore, the dissolved oxygen content of the SCS below $-1500 \mathrm{~m}$ is less than that in the same depth of the West Pacific [61]. Two distinct tectonic units appear in the Luzon Strait between Taiwan and Luzon Islands: the Hengchun Ridge accretionary prism and the Luzon Volcanic Arc (Inserted map in Figure 1). Consequently, formation of the modern SCS deep basin water circulation is closely linked to the tectonic evolution of the accretionary prism and the Luzon Arc in the Taiwan region. The Hengchun Ridge accretionary prism extends for more than $700 \mathrm{~km}$ from offshore west of the Luzon Island (water depth: $-2400 \mathrm{~m}$ ) to southern Taiwan (water depth $<-200 \mathrm{~m}$ ), then exposes northward as the Hengchun Peninsula-Central Range (Figure 1), while the North Luzon Arc extends from the Luzon Island northward through the Babuyan-Batan-Lanyu-Lutao volcanic islands to the Coastal Range in eastern Taiwan (Figure 1). Each volcanic island represents an eruption center and between volcanic islands there is a deep inter-arc passage, for example the Bashi Strait ( -2400 to $-2600 \mathrm{~m}$ deep; Figure 1) between the Lanyu and Batan volcanic islands, which is the main entrance for the Deep Water of the West Pacific flowing westward into the SCS deep basin. Therefore, driving mechanisms responsible for changes of the SCS deep sea paleoceanography are strongly related to the geological evolutions of: (1) the eastward subduction of the SCS oceanic lithosphere along the Manila Trench to develop bathymetric highs of the Hengchun Ridge accretionary prism and the Luzon volcanic arc; (2) the exposure 
of the Hengchun Ridge as the modern Hengchun PeninsulaCentral Range, and (3) closing of the inter-arc passages between volcanic islands in the Taiwan segment.

\subsection{SCS Miocene paleoceanography records}

Paleoceanographic research on the ODP 1148 deep-sea core indicates that the Early Miocene SCS carbon isotope stratigraphy of benthic foraminifers is similar to the West Pacific deep-sea records. But in the last $16 \mathrm{Ma}$ the benthic foraminiferal carbon isotope values of the SCS fluctuated significantly and were much more negative than the West Pacific records [14,62]. In addition to global carbon reservoir effect, carbon isotope values of benthic foraminifers are controlled by multiple factors, for examples surface productivity, and source, path, age and mixtures of the deep water. Therefore, the benthic foraminiferal carbon isotope stratigraphy of ODP 1148 core will fundamentally reflect not only the global signals of ocean-atmosphere interactions, but also the local influences of the source, path, circulation and mixture of the SCS deep basin water. After filtering out global carbon and oxygen isotope signals from SCS deepsea records, it will appear the local factors that might drive the SCS deep-sea paleoceanographic changes.

\subsection{Paleoceanography of the semi-closing SCS linked to tectonic evolution of the Hengchun Ridge}

Incipient formation and final exposure of the Hengchun Ridge accretionary prism above sea-level are two import factors to cause paleoceanographic fluctuations of the semiclosing SCS since the Middle Miocene. The former starts to block the West Pacific Bottom Water (>-2500 m) flowing westward into the deep SCS, while the latter reduces at least $400 \mathrm{~km}$ wide of the seaway for water exchanges between the West Pacific and the SCS. However, the incipient event to develop the Hengchun accretionary prism is hard to estimate from the stratigraphy or the deformation history of the accretionary prism itself, but can be indirectly evaluated by the earliest volcanism age of the Luzon arc [63]. The reliable age of the earliest volcanism of the Northern Luzon arc in the Taiwan segment is the Middle Miocene (15-16 Ma) [64]. This indicates that the SCS oceanic lithosphere must have already subducted eastward along the Manila Trench in 15-16 Ma. The passive margin sequences on the SCS outer shelf-slope and deep-sea basin are scrapped off into the Hengchun Ridge accretionary prism (Figure 12). The prism is thus growing up wider and uplifted to block the connection of bottom waters (>-2500 m) between the West Pacific and the SCS. Therefore, this may lead to a stagnant SCS bottom water circulation. Consequently in the deep SCS, carbon isotope values of benthic foraminifers in the last $14 \mathrm{Ma}$ (Steps (II) and (III)) were much more negative than in 26-14 Ma (Step I; Figure 10).

Three tectonostratigraphic units are exposed in the
Hengchun Peninsula (Figure 12, left): Middle-Late Miocene flysch sequences, late Miocene Kenting Mélange of the subduction complex, and the Plio-Pleistocene slope basin sequences [6]. The flysch sequences are Middle-Late Miocene continent-derived turbidites deposited on the slope of the northeastern SCS. The youngest deep-sea flysch strata in the deformed accretionary prism is dated as the latest Miocene (Zone NN11, 8 Ma) [6,65], indicating that the Hengchun Ridge accretionary prism was formed in 15-8 Ma (Figure 12(a)). The arc-continent collision started from 6.5 Ma further pushed the accretionary prism upward and exposed as the proto-Central Range (Figure 12(b)). Sediments shed from this Proto-Central Range are accumulated in the foreland basin (<6.5 Ma) now exposed in the Western Foothills, the forearc basin in the Coastal Range, and the Maanshan Formation $(4.5-\sim 1 \mathrm{Ma})$ in the lowest part of the slope basin unconformably overlying the accretionary prism in the Hengchun Peninsula (Figure 12(b)) [6,63]. Accordingly, by 4-4.5 Ma the modern Hengchun Peninsula-Central Range configuration had already formed. This would reduce at least $400 \mathrm{~km}$ wide (the length of Taiwan island) of the seaway for water exchanges between the West Pacific and the SCS. This age also suggests that the modern SCS circulation could have developed since $4.5 \mathrm{Ma}$ and would be responsible for a much more negative carbon isotope of benthic foraminifers of Step III in ODP 1148 core (Figure 10). This also reveals that in addition to the global Messian salinity crises ( 6.5 Ma), the tectonic evolution of the Hengchun Ridge accretionary prism also plays an important role linked to the SCS deep sea paleoceanography.

\subsection{Paleoceanography of semi-closing SCS linked to tectonic evolution of the North Luzon volcanic arc}

Eastward subduction of the SCS oceanic lithosphere also resulted in volcanism of the North Luzon volcanic arc since the Middle Miocene. The North Luzon volcanic arc is composed of volcanic island chain of (from north to south) Chimei, Chengkuangao Islands (now accreted to the Coastal Range, eastern Taiwan [66]; Figure 13), Lutao, Lanyu Islands in the initial arc-continent collision zone off SE Taiwan, and Batan and Babuyan Islands of the Philippines in the intra-oceanic subduction zone (Figure 1). In each volcanic island, agglomerates are piled up from $-5500 \mathrm{~m}$ depth of the Huatung basin to above sea level to become a bathymetric barrier to block bottom water exchange between the West Pacific and the SCS. However, between volcanic islands there is always an inter-arc passage $(-2500$ to $-3000 \mathrm{~m}$ water depth; Figure 1) through which the West Pacific Deep Water flows westward into the SCS deep basin. Therefore, the more, wider and deeper the inter-arc passages, the more easily West Pacific Deep Water can flow westward into the SCS deep basin, and vise versa.

The Coastal Range is composed of four remnant forearc basins, two independent volcanic islands, two intra-arc 


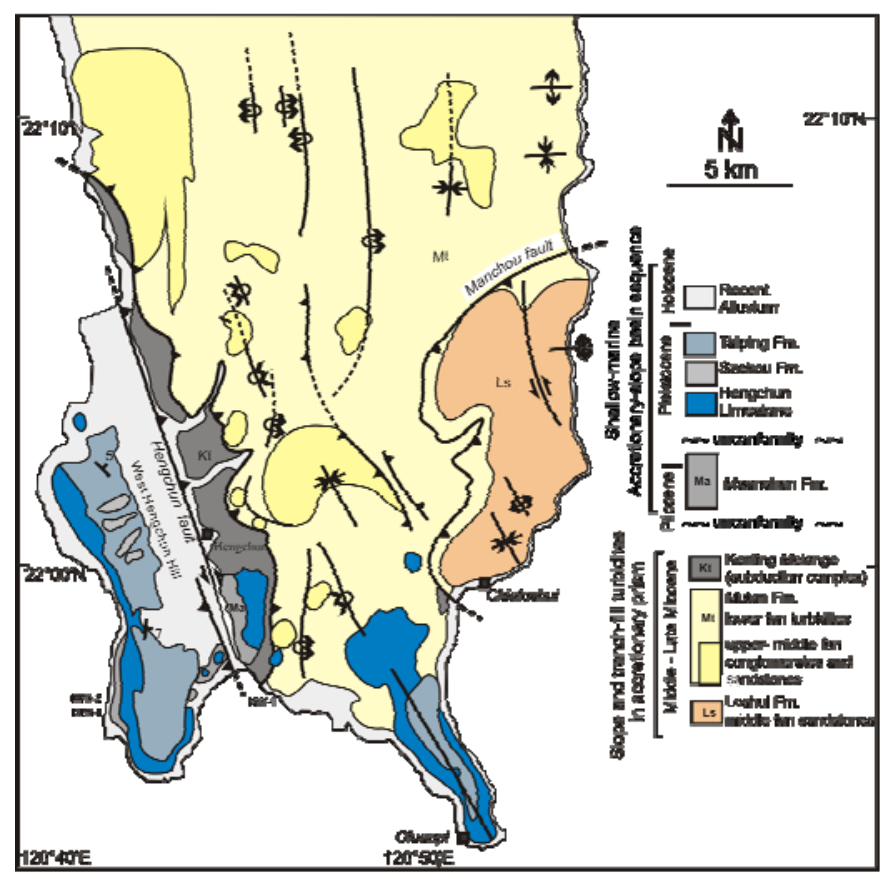

West

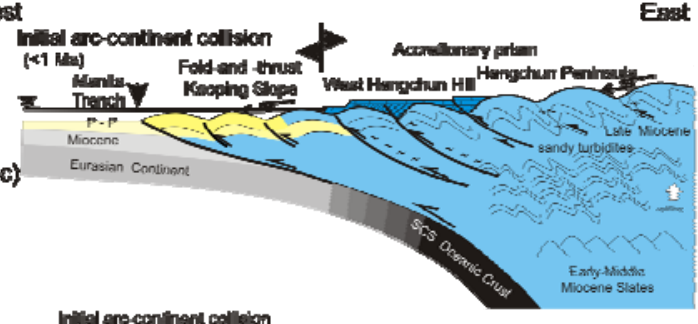

Enst

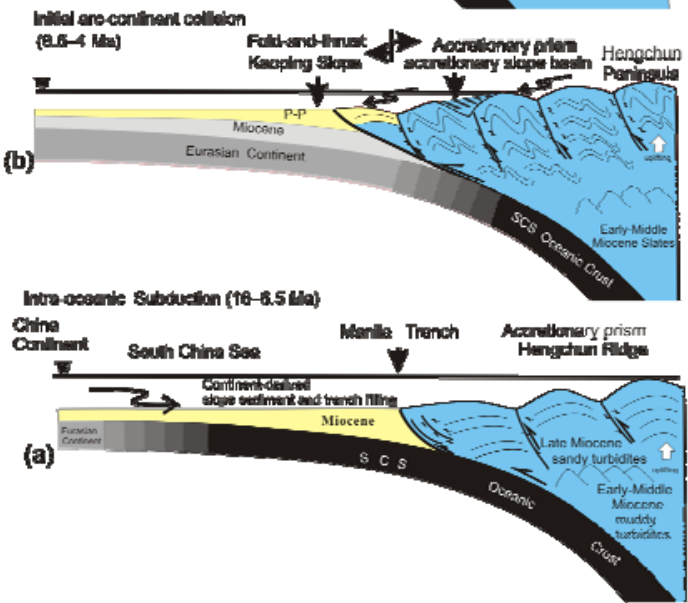

Figure 12 Geological map (left) and tectonic evolution (right) of the Hengchun Peninsula accretionary prism [6,65]. Left: The Hengchun Peninsula is composed of three tectonic units: Late Miocene turbidites, Late Miocene Kenting Mélange and Plio-Pleistocene slope basin unconformably overlying the deformed accretionary prism. Right: The Hengchun Peninsula has experienced intra-oceanic subduction tectonics and initial arc-continent collision tectonics (Figure 1). (a) During the Intra-oceanic subduction stage (16-6.5 Ma), the SCS oceanic lithosphere subducted eastward along the Manila Trench to produce the Hengchun Ridge accretionary prism and the Luzon Arc (not shown in map); (b) In early initial arc-continent collision stage (6.5-4 Ma), the Hengchun Ridge was exposed as the proto-Central Range. Sediments eroded from the exposed accretionary prism are deposited in the slope basin unconformably on the accretionary prism and the foreland basin west of the Manila Trench. Meantime, the Manila Trench migrates westward and changes its geological role from a subduction trench to a deformation front of the fold-and-thrust belt; (c) Now $(<1 \mathrm{Ma})$ the slope basin is further deformed and tilted as the West Hengchun Hill, while the foreland sequence is deformed as the fold-and-thrust Kaoping Slope off SW Taiwan. P-P: Pliocene-Pleistocene.

basins and a forearc collision mélange [7,66] (Figure 13). Remnant forearc basins (from north to south: Shuilien, Loho, Taiyuan and Taitung) are located west of the volcanic islands and are aligned in a N-S direction. They are parts of the North Luzon Trough forearc basin and are filled by Pliocene- Pleistocene turbidite sequences (including fan delta and deep-sea fan conglomerates) primarily eroded from the exposed accretionary prism to the west with subordinately shed from the Luzon volcanic arc to the east. During the initial arc-continent collision in the last $3.5 \mathrm{Ma}$, the western part of North Luzon Trough was eastward back-thrust to develop the modern Huatung Ridge [66,67] (Figures 1 and 14). Therefore, the North Luzon Trough narrows northward [7,9] (Figure 1), while the un-deformed eastern part of the North Luzon Trough thus appears as remnant forearc basins (Figure 1). The eastward thrust Huatung Ridge was further westward obducted and sheared to mix with the oceanic crust and upper mantle rocks beneath the forearc basin as the Lichi Mélange during the advanced arc-continent collision stage in the last $2 \mathrm{Ma}[67,68]$ (Figure 13).

Two accreted volcanic islands (the Chimei volcanic island in the north and the Chengkuangao volcanic island in the south) were accreted onto the Coastal Range during the advanced stage of arc-continent collision in the last $2 \mathrm{Ma}$
[66] (Figure 13). The two small remnant forearc basins connects also to the inter-arc passage: the Loho Basin in the north between the Chimei volcanic island and the Chengkuangao volcanic island, and the Taitung basin in the south between the Chengkuangao volcanic island and the Lutao volcanic island off the southern Coastal Range, respectively (Figure 13).

The NW motion of the Philippine Sea Plate also pushes the Huatung Ridge pop-upward which also leads to deformations of the inter-arc passage between volcanic islands like what happens today between the Lutao and Lanyu volcanic islands in the initial arc-continent collision zone off SE Taiwan (marked as $\mathrm{X}$ in Figure 14). Accordingly, the inter-arc passage between the Lutao and Lanyu volcanic island is partially closing (Figure 14), which acts like a sedimentary dam that the modern sediments in the Taitung Trough (a modern remnant forearc basin west of the Lutao volcanic island, Figure 14) cannot pass over. Therefore, they are now transported eastward via the Taitung Canyon to the Huatung Basin east off Taiwan (Figure 14). Once the remnant forearc basin and inter-arc passage are deformed, the entrance route for the West Pacific Deep Water to flow westward into the SCS deep basin is semi-closed too.

Forearc strata in the Loho remnant forearc basin are dated as 4.2-3.6 $\mathrm{Ma}[69,70]$ by planktic foraminifers and 


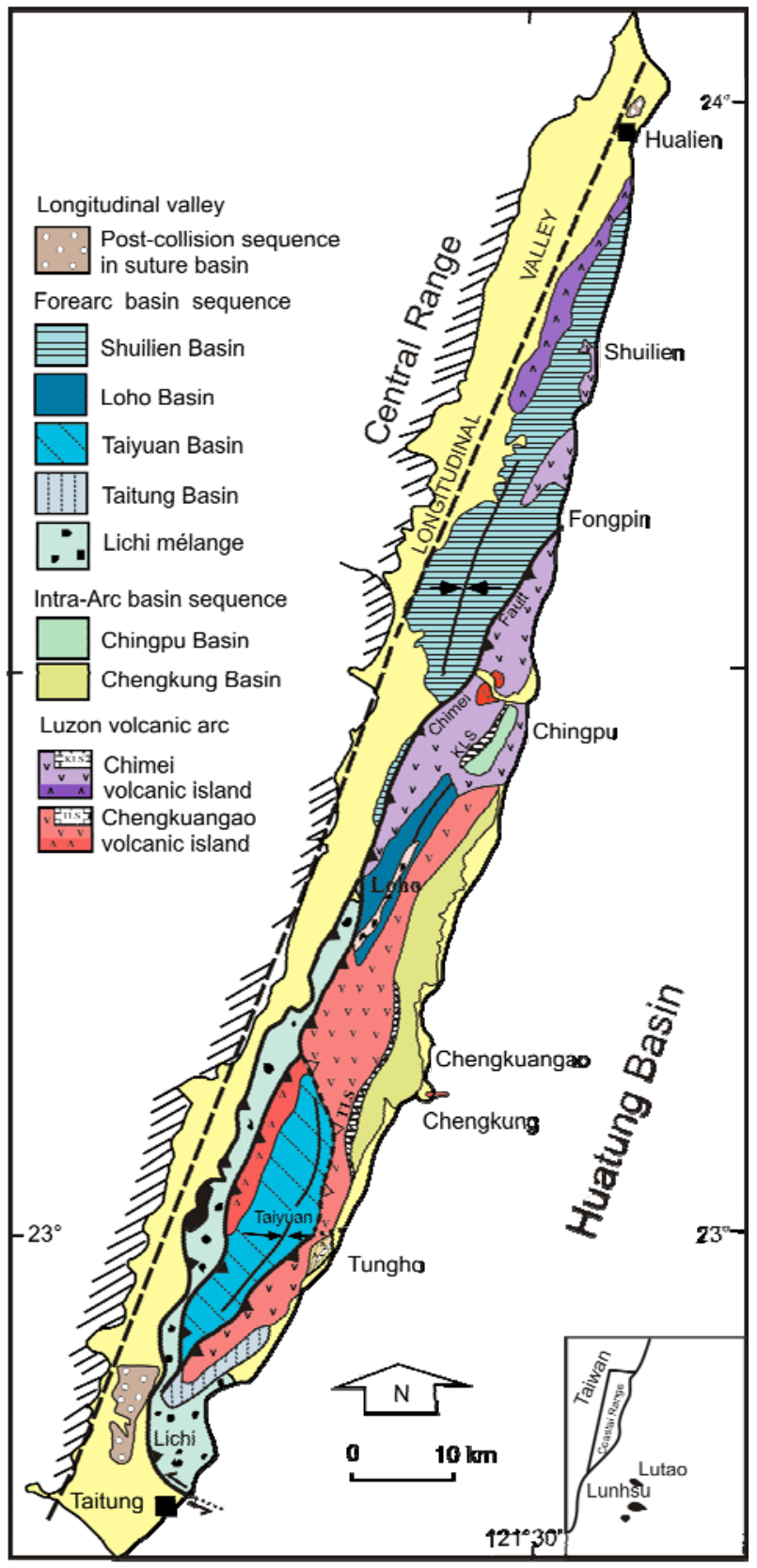

Figure 13 Tectonostratigraphic map of the Coastal Range in eastern Taiwan (modified from [7]). The Coastal Range is composed of four remnant forearc basins (Shuilien, Loho, Taiyuan and Taitung), two volcanic islands (Chimei and Chengkuangao) associated two intra-arc basins and a forearc collision Lichi Mélange [67,68]. The Loho Basin and Taitung Basin also connect to the inter-arc passage between volcanic islands.

calcareous nannoplanktons. This indicates that the Loho Basin, also the inter-arc passage between the Chimei volcanic island and the Chengkuangao volcanic island, was deformed and thus semi-closed at $\sim 3.5 \mathrm{Ma}$. The West Pacific Deep water can no longer flow westward into the SCS deep basin through the semi-closed Loho remnant forearc basin and inter-arc passage. Like the Loho Basin in the north, the Taitung remnant forearc basin, also the inter-arc passage between the Chengkuangao (onshore southern Coastal
Range) and the Lutao volcanic islands, in the south was deformed in the early Pleistocene ( 1 Ma) [70] (Figure 14). Moreover in the last $1 \mathrm{Ma}$, remnant forearc basins and the Chimei-Chengkuangao volcanic islands were obducted westward and exposed as the modern Coastal Range in eastern Taiwan (Figure 13). Accordingly, the Loho and Taitung inter-arc passages are totally closed respectively at 3.5 Ma and $\sim \mathrm{Ma}$, while the modern inter-arc passage between the Lutao volcanic island and the Lanyu volcanic island off SE Taiwan is closing now (Figure 14). The instability of water exchanges between the West Pacific and the SCS, due to closures of the inter-arc passages in the last 4 $\mathrm{Ma}$, results in highly fluctuating and negative carbon isotope values of benthic foraminifers in Step (III) of the ODP 1148 deep sea core (Figure 10).

\section{Conclusions}

The Cenozoic stratigraphy exposed in the Taiwan mountain belt is composed of the Paleozoic (?)-Mesozoic pre-rifting basement, Paleocene-Middle Eocene syn-rifting strata and Late Oligocene-Neogene post-rifting sequences. They are separated from each other by the pre-rifting unconformity and the break-up unconformity. Taiwan Cenozoic strata are all deposited in the passive continental margin of the northern SCS before deformations by a plate convergence that the SCS oceanic lithosphere subducted eastward beneath the Philippine Sea Plate since the Middle Miocene. Accordingly, the Taiwan Cenozoic stratigraphy represents a geological window of the northeastern SCS shelf sequences looking into the SCS tectonic evolution from opening to semi-closing:

(1) A regional break-up unconformity between Middle Eocene syn-rifting sequences and Late Oligocene-Miocene post-rifting strata exists throughout Taiwan mountain belts and offshore Taiwan Strait. This break-up unconformity was known as the "Puli Orogeny" by which Late Eocene-Early Oligocene deposits between 33 and 39 Ma are completely missing. This break-up unconformity in Taiwan could be equivalent to the $\mathrm{T}_{7}$ unconformity or the Nanhai Orogeny in the northern SCS.

(2) The Paleocene-Eocene rifting basin was developed by normal faulting in the passive Asian continental margin. The Paleogene rifting associated with a thermal upwelling of magma would further lead to formation of the SCS oceanic crust. The break-up unconformity in the Taiwan mountain belt suggests indirectly that the SCS oceanic crust could initiate in 33-39 Ma.

(3) In the Western Foothills onland Taiwan and the offshore Taiwan Strait, neither stratigraphic gap nor slumping features are found in the sequence near the Oligocene/Miocene boundary. This is highly contrasted to what are recorded in the ODP 1148 deep-sea core. This difference suggests that both stratigraphic gap and slumping features near Oligocene/Miocene boundary could just occur in the SCS deep 


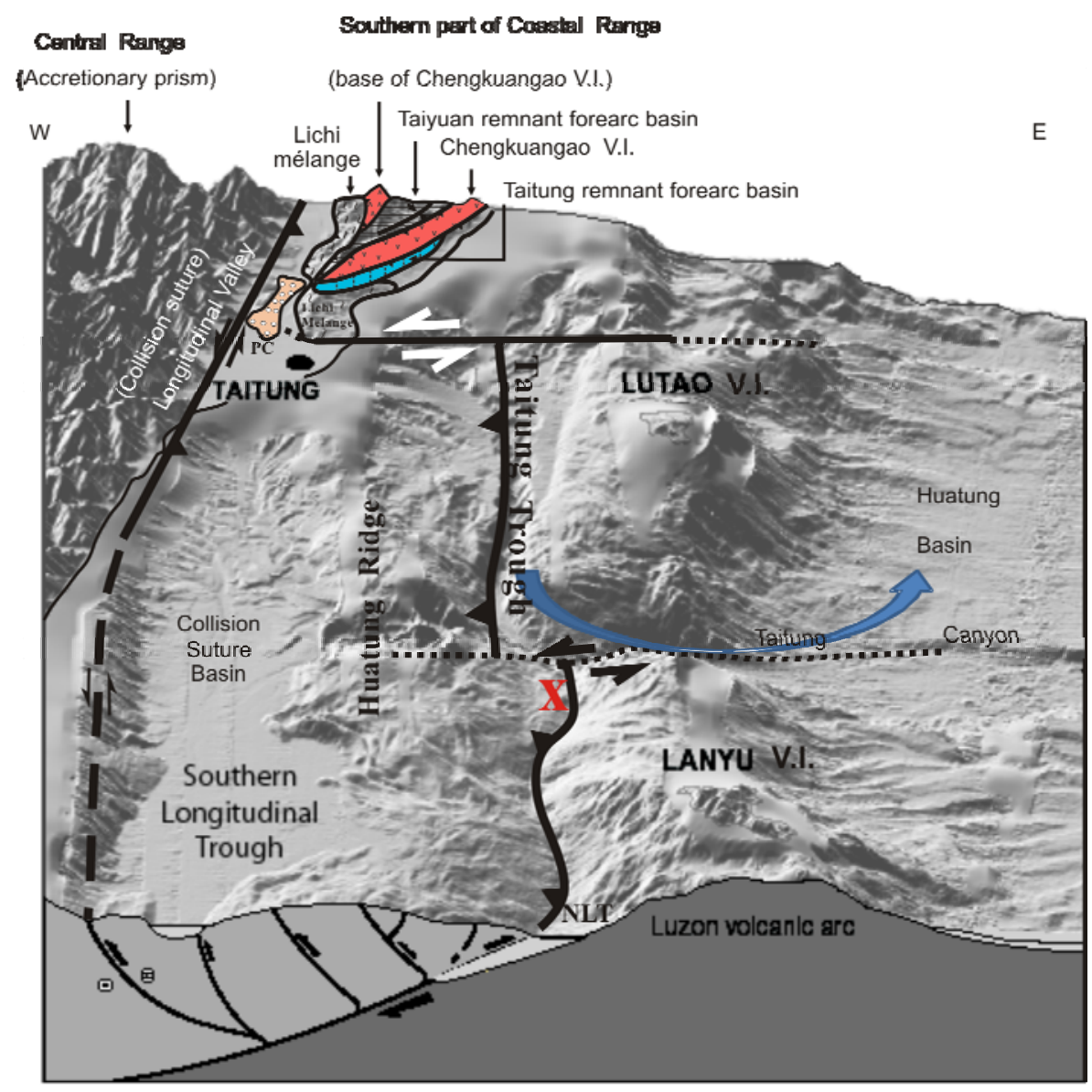

Figure 14 3-D images in the initial arc-continent collision zone off SE Taiwan (base map adapted from [71]). The western part of the North Luzon Trough forearc basin is eastward back-thrust to develop the Huatung Ridge. The remaining part of the un-deformed forearc basin thus occurs as remnant forearc basins. The inter-arc passage between the Lutao and the Lanyu volcanic islands is also deformed as part of Huatung Ridge (marked as X). The Huatung Ridge acts as a sedimentary dam that the modern sediments in the Taitung Trough can no longer pass over. Consequently, modern sediments can only be transported eastward (blue arrow) via the Taitung Canyon to the Huatung basin east off Taiwan. PC: Peinanshan Conglomerate.

basin but not in the SCS shelf stratigraphy exposed in Taiwan.

(4) Comparing to the paleoceanographic re-organization since the Middle Miocene in the SCS deep sea basin, Taiwan Cenozoic stratigraphy reveals a complicate geohistory in both sedimentology and paleontological aspects. In sedimentology aspects, sedimentation is progressive shallowing upward from the Talu Shale during the Miocene Optimum and highest sea-level stand (16-14.5 Ma), through shelf strata of the Kuanyinshan Sandstone (14.5-13.5 Ma) to the coastal dune sands and swamp environments of the coalbearing Nanchuang Formation during the lowest sea-level stand (13.5-10 Ma). This shallowing deposition is due to the Antarctic ice dramatically expansion. In the meantime, there is also a distinct decrease of faunal abundance, diversity and faunal turnover event (Post Taluan Faunal Break) occurred in Middle/Late Miocene boundary. Many EarlyMiddle Miocene endemic benthic foraminifers are extinct before 12.9 Ma. The Middle fauna are replaced by modern fauna living in the Asian continental shelf flowed by the Kuroshio Current at 10.2 Ma. This observation suggests the modern Kuroshio Current could develop in 12.9-10.2 Ma by intensification of the West Boundary Current in the North Pacific due to closures of the Indo-Pacific seaway by conve rgent tectonics of subduction and collision between the Australian continent and the Indonesian volcanic arc in 12-8 Ma. The Taiwan faunal turnover event occurred in the Middle/Late Miocene boundary is coeval with a shift of benthic foraminiferal oxygen isotope stratigraphy from Step (I) to Step (II) (15-12 Ma) in the ODP 1148 deep-sea core.

(5) The mechanism responsible for the SCS semi-closing is highly linked to the subduction of the SCS oceanic lithosphere beneath the Philippine Sea Plate to develop the Hengchun Ridge accretionary prism and the Luzon volcanic arc between Taiwan and Luzon Islands since Middle Miocene. Approaching Taiwan, the Hengchun Ridge accretionary prism exposes as the Hengchun Peninsula-Central Range, while the northern part of the Luzon volcanic arc has been accreted westward onto eastern Taiwan as the Coastal Range. Both Hengchun Ridge accretionary prism and the North Luzon volcanic arc act as bathymetric highs to hamper water exchanges between the West Pacific and the SCS. Occurrences of these bathymetric highs also cause a change of 
geochemistry (especially carbon isotope values of benthic foraminifers) of the SCS deep basin water and fluctuations of SCS paleoceanography. These paleoceanographic events include deformations of accretionary prism to block the West Pacific Bottom Water flowing into the SCS deep basin (15-8 Ma), formation of modern Hengchun PeninsulaCentral Range to reduce at least $400 \mathrm{~km}$ wide seaway for water exchanges between the West Pacific and the SCS (6.5-4 Ma), and semi-closure of the Loho Basin and Taitung Basin between volcanic islands that the West Pacific Deep Water can no longer flow westward through these inter-arc passages into the SCS (3.5 Ma, 1 Ma, respectively). Now, the inter-arc passage between the Lutao and Lanyu volcanic islands is semi-closing (0 Ma). During these events, ODP 1148 core shows high fluctuations of negative carbon isotope values of benthic foraminifers, suggesting instability of water exchanges between the West Pacific and the SCS and also a closely relationship between the tectonic evolution of Taiwan mountain building and the SCS paleoceanography in the last $14 \mathrm{Ma}$.

The authors thank Yao B C and Huang YY of the Guangzhou Marine Geological Survey, and Wang $P$, Jian $Z$, Tian $J$ and $W u G X$ of the Tongji University, for their constrictive discussions on the stratigraphy of the Pearl River Mouth Basin and paleoceanography of the South China Sea. This work was supported by the National Natural Science Foundation of China (91128211 and 41176041) and the Knowledge Innovation Program of the Chinese Academy of Sciences (KZCX2-EW-101).

1 Taylor B, Hayes D E. The tectonic evolution of the South China Sea. In: Hayes D E, ed. The Tectonic and Geological Evolution of Southeast Asian Seas and Islands, Part I. AGU Monogr, 1980, 23: 89-104

2 Yao B, Zeng W, Hayes D E, et al, The geological memoir of South China Sea Surveyed Jointly by China and USA. Beijing: China University of Geosciences Press, 1994, 204

3 Taylor B, Hayes D E. Origin and history of the South China Sea Basin. In: Hayes D E, ed. The Tectonic and Geological Evolution of Southeast Asian Seas and Islands, Part II. AGU Monogr, 1983, 27: 23-56

4 Tsai Y B. Seismotectonics of Taiwan. Tectono. 1986, 125: 17-37

5 Huang C Y, Shyu C T, Lin, S B, et al. Marine geology in the arc-continent collision zone off southeastern Taiwan: Implications for late $\mathrm{Ne}$ ogene evolution of the Coastal Range. Mar Geol, 1992, 107: 183-212

6 Huang C Y, Wu W Y, Chang C P, et al. Tectonic evolution of accretionary prism in the arc-continent collision terrane of Taiwan. Tectonophy, 1997, 281: 31-51

7 Huang C Y, Yuan P B, Lin C W, et al. Geodynamic processes of Taiwan arc-continent collision and comparison with analogs in Timor, Papua New Guinea, Urals and Corsica. Tectonophy, 2000, 325: 1-21

8 Sun S C. The Tertiary basins of offshore Taiwan. Proc 2nd ASCOPE Conference and Exhibition, Manila, Philippines, 1982, 125-135

9 Reed D L, Lundberg N, Liu, C S, et al. Structural relations along the margins of the offshore Taiwan accretionary wedge: Implications for accretion and crustal kinematics: Acta Geol Taiwan, 1992, 30: 105-122

10 Wang P, Li Q. The South China Sea. Paleoceanography and Sedimentology. Heidelberg: Springer: 2009, 515

11 Wang P, Prell W L, Blum P. Proceeding of ODP Init. Repts. 184 (CD-ROM). Ocean Drilling Program, Texas A\&M University, College Station, 2000, TX77845-9547

12 Li Q, Wang P, Zhao Q, et al. A 33 Ma lithostratigraphic record of tectonic and paleoceanographic evolution of the South China Sea. Mar Geol, 230: 217-235

13 Tian J, Shevenell A, Wang P, et al. Reorganization of Pacific Deep
Waters linked to middle Miocene Antarctic cryosphere expansion: A perspective from the South China Sea. Paleogeogr Paleoclimatol Paleoecol, 2009, 284: 375-382

14 Zhao Q, Jian Z, Wang P, et al. Neogene oxygen isotopic stratigraphy, ODP Site 1148, northern South China Sea. Sci China Ser D, 2001, 44: 939-942

15 Zhao Q, Wang P, Cheng X, et al. A record of Miocene carbon excursions in the South China Sea. Sci China Ser D, 2001, 44: 943-951

16 Hsiao P T, Hu C C, Lin K A, Hydrocarbon potential evaluation of the Penghu Basin. Petrol Geol Taiwan,. 1991, 26: 215-229

$17 \mathrm{Yu} \mathrm{J} \mathrm{W,} \mathrm{Radiometric} \mathrm{ages} \mathrm{of} \mathrm{the} \mathrm{igneous} \mathrm{bodies} \mathrm{in} \mathrm{the} \mathrm{wells} \mathrm{in} \mathrm{the}$ Western central Taiwan (in Chinese). Chin Petrol Comp Expl Dev Res Bull, 1981, 4: 363-366

18 Huang T C, Chi W R. Calcareous nannofossils of the subsurface PreMiocene rocks from the Peikang Basement High and adjacent areas in western Central Taiwan (Part II: Paleocene). Petrol Geol Taiwan, 1979, 16: 95-129

19 Huang C Y, Significance of Eocene extension basin sequences in the northern Western Foothills: A key point in study of Hsüehshan Range stratigraphy (in Chinese). Central Geol Surv Spec Publ, 2009, 22: 47-62

20 Huang C Y, Chi W R, Yan Y, et al., The first record of Eocene sequence in a marine Paleogene rifting basin near Nantou, Western Foothills, central Taiwan. J Asian Earth Sci, 2012

21 Huang C Y, Chi W R, Liew P M, et al. Significance of indigenous Eocene larger foraminifers Discocyclina dispansa in Western Foothills, central Taiwan: A Paleogene marine rifting basin in Chinese continental margin. J Asian Earth Sci, 2012

22 Ho C S, Tsan S F. Tan, L.P. Geology and coal deposit of the Chichitashan area, Nantou, Taiwan. Geol Surv Taiwan Bull, 1956, 9: 1-80

23 Ho, CS. Correlation of the Takeng Formation and some related stratigraphic principles. Proc Geo. Soc Chin, 1961,4: 61-71

24 Huang C Y, Cheng Y M. Oligocene and Miocene planktic foraminiferal biostratigraphy of northern Taiwan. Proc Geol Soc China, 1983, 26: 21-56

25 Huang C Y. Oligocene and Miocene stratigraphy of the Kuohsing area, central Taiwan. Acta Geol Taiwan, 1986, 24: 281-318

26 Huang T C. Calcareous nannoplankton, paleoenvironment, age and correlation of the Upper Wulai Group and the Lower Hsichih Group (Oligocene to Miocene) in northern Taiwan. Proc Geol Soc China, 1978, 21: 128-150

27 Huang T C, Ting J S. Calcareous nannofossils succession from the Oligo-Miocene Peikangchi section and revised stratigraphic correlation between northern and central Taiwan. Proc Geol Soc Chin, 1979, 22: $105-120$

28 Chang L S. Tertiary biostratigraphy of Taiwan. Geol Paleontol SE Asia, 1975, 15: 337-361

29 Chang L S. A biostratigraphic study of the Oligocene in northern Taiwan based on smaller foraminifera. Proc Geol Soc Chin, 1962, 5: 47-52

30 Huang T C. Calcareous nannoplanktons stratigraphy of the Upper Wulai Group (Oligocene) in northern Taiwan. Petrol Geol Taiwan, 1977, 14: 147-179

31 Huang C Y, Micropaleontology study and stratigraphic correlation in northern Hsüehshan Range, Taiwan (I) (in Chinese). Central Geol Surv MOEA, 2008, 1-31

32 Huang C Y, Micropaleontology study and stratigraphic correlation in northern Hsüehshan Range, Taiwan (I). Central Geol Surv MOEA, 2008, 1-31 (in Chinese, unpublished)

33 Kanno S, Chung C T, Tertiary formations and their molluscan faunas from the Central Rang and foothill areas of northern Taiwan. Contri Geol Paleont SE Asia, 1975, 15: 363-391

34 Huang C Y, Micropaleontology study and stratigraphic correlation in northern Hsüehshan Range, Taiwan (II) (in Chinese). Central Geol Surv MOEA, 2009, 1-49

35 Fong C K, Huang T, Shea K S. New occurrence of larger Foraminifera in northern Taiwan and its stratigraphic significance. Cent Geol Surv Spec Publ, 1994, 8: 205-212

36 Matsumaru, K. Nummilites junbarensis and Assilina formosensis (late Early to early Middle Eocene) from Taiwan (Formosa). Revue Palébiol Genève, 2005, 24: 551-561 
37 Chen M M, Yu N T, Chu H T, Larger foraminifers in the so-called "Meichi Sandstone" of Wujie area, southern Hsuehshan Range (in Chinese). Central Geol Surv Spec Publ, 2009, 22: 227-242

38 Yen $\mathrm{T}$ P. The Eocene sandstones in the Hsuehshan Range Terrain, northern Taiwan. Proc Geol Soc Chin, 1973, 16: 97-110

39 Huang T C. A calcareous nannofossils biostratigraphic study of the Assilina-bearing section, Chunkengchi, Nantou. Proc Geol Soc Chin, 1980, 23: 7-15

40 Blow W H. Late Middle Eocene tp Recent planktonic foraminiferal biostratigraphy. In, Bronnimann, P, Renz H H, Eds, Proceedings of the First International Conference on Planktonic Microfossils, 1: 199-421

41 Wade B S, Pearson P N, Berggren W A, et al. Review and revision of Cenozoic tropical planktonic foraminiferal biostratigraphy and calibration to the geomagnetic polarity and astronomical time scale. Earth Sci Rev, 2011, 104: 111-142

42 Lee C T, Wang Y, Stratigraphy and structure of the slate terrane near Likuan, southern cross-island highway (in Chinese). Ti-Chih, 1985, 6: 1-20

43 Chang L S. The Lushanian Stage in the Central Range of Taiwan and its fauna. In: Takayanagi Y, Saito T, eds. Progress In Micropaleontology. The American Museum of Natural History, New York: Micropaleontology Press, 1976, 27-35

44 Huang T C. Calcareous nannofossils from the Slate Terrane west of Yakou, Southern Cross-Island Highway. Petrol Geol Taiwan, 1980, 17: 59-74

45 Hashimoto W, Matsumaru K. On the Lepidocyclina-bearing limestone exposed at the Southern Cross-Mountain Highway, Taiwan. Geol Paleont SE Asia, 1975, 16: 103-116

46 Chang L S. Eocene/Miocene hiatus and N Conglomerate in the Central Range of Taiwan. Proc Geol Soc Chin, 1972, 15: 93-98

47 Chang L S, Stratigraphy of Taiwan. Quart J Taiwan Bank, 1955, 7: $1-7$

48 Pang X, Chen C M, Shi H S, et al., The Pearl River Deep-water Fan System \& Petroleum in South China Sea. Beijing: Science Press, 2007. 266

49 Briais A, Patriat P, Tapponnier P. Update interpretation of magnetic anomalies and seafloor spreading stages in the South China Sea: Implication for the Tertiary tectonics of southeast Asia. J Geophys Res, 1993, 98: 6299-6328

50 Huang C Y. Late Oligocene benthic foraminiferal assemblages in northern Taiwan: The Second International Symposium on Benthic Foraminifera, Pau, France, 1984, 317-323

51 Huang, T C. A supplementary note on the calcareous nannofossils, age, and correlation of the Wuchihshan Formation. Petrol Geol Taiwan, 1979, 16: 85-93

52 Huang C Y. Biometric study of Lepidocyclina in the Kungkuan Tuff of northern Taiwan. Acta Geol Taiwan, 1979, 20: 41-51

53 Haq B U, Hardenbol J, Vail P R. Chronology of fluctuating sea level since the Triassic. Science, 1987, 235: 1156-1167

54 Huang, T C. The Oligocene/Miocene boundary in Taiwan. Memoir Geol Soc Chin, 1979, 3: 103-123

55 Miller K G, Fairbank R G, Mountain G S. Tertiary oxygen isotope synthesis, sea level history, and continental marine erosion. Paleocean- ology, 1987, 2: 1-19

56 Woodruff F, Douglas R G. Response of deep-sea benthic foraminifera to Miocene paleoclimatic events, DSDP Site 289. Mar Micropal, 1981, 6: 617-632

57 Huang C Y. Implication of the Post-Lushanian faunal change for the occurrence of Kuroshio Current in the early late Miocene: foraminiferal evidence from the Chuhuangkeng section, northern Taiwan. Proc Geol Soc Chin, 1989, 32: 21-45

58 Chang L S. A biostratigraphic study of the Miocene in western Taiwan based on smaller foraminifera (Part II: benthonics). Bull Geol Surv Taiwan, 1960, 12: 67-91

59 Wang P, Zhang J, Qinbao M. Distribution of foraminifera in surface sediments of the East China Sea. In Wang P. ed. Marine Micropaleontology of China. Berlin: Spring-Verlag, 1985. 34-69

60 Kennett J P, Keller G, Srinivasan M S. Miocene planktonic foraminiferal biogeography and paleoceanographic development of the IndoPacific region. Geol Soc Amer Mem, 1985, 163: 197-236

61 Qu T, Girton, J B, Whitehead, J A. Deepwater overflow through Luzon Strait. JGR,111, CO1002, doi:10.1029/2005JC003139

62 Zachos J, Pagani M, Sloan L, et al. Trends, rhythms, and aberrations in global climate $65 \mathrm{Ma}$ to present. Science, 2001, 292: 686

63 Huang C Y, Yuan P B, Tsao S J. Temporal and spatial records of active arc-continent collision in Taiwan: A synthesis. Geol Soc Amer Bull, 2006, 118: 274-288

64 Yang T Y, Liu, T K, Chen C H. Thermal event records of the Chimei igneous complex: constraint on the ages of magma activities and the structural implication based on fission track dating. Acta Geol. Taiwan, 1988, 26: 237-246

65 Chang L S, A biostratigraphic study of the Tertiary in the Hengchun Peninsula, Taiwan, based on smaller foraminifera (III: Southern Part). Proc Geol Soc China, 1966, 9: 55-63

66 Huang C Y, Yuan P B, Song S R, et al, Tectonics of short-lived intraarc basins in the arc continent collision terrane of the Coastal Range, eastern Taiwan. Tectonics, 1995, 14: 19-38

67 Chang C P, Angelier J, Huang C Y, et al. Structural evolution and significance of a mélange in a collision belt: the Lichi Mélange and the Taiwan arc-continent collision. Geol Maga, 2001, 138: 633-651

68 Huang C Y, Jien C W, Chang C P, et al. The Lichi Mélange: A tectonic collision complex originated form sheared forearc in Coastal Range, eastern Taiwan. Geol Soc Amer Spec Paper, 2008, 436: 127-154

69 Lin Y C, Evolution of Loho remnant forearc basin and significance of the Lichi Mélange in the basin, Coastal Range, eastern Taiwan: Micropaleontology and clay mineral assemblage evidences (in Chinese). Master's Thesis, Department of Earth Sciences, Cheng Kung University, 2010, 50

70 Huang C Y, Zhao Q, Jian Z. Fluctuations of bottom water paleoceanography of South China Sea linked to tectonic evolution of accretionary prism-Luzon volcanic arc in Taiwan region. AGU Fall Meeting, EOS, OS54A-03.

71 Malavieille J, Lallemand S E., Dominguez, S, et al. Arc-continent collision in Taiwan: New marine observations and tectonic evolution. Geol Soc Ame, Special Paper, 2002, 358: 187-211

Open Access This article is distributed under the terms of the Creative Commons Attribution License which permits any use, distribution, and reproduction in any medium, provided the original author(s) and source are credited.

\section{Supporting Information}

Figure S1 Sampling locations in five study sections in the Hsúehshan Range, northern Taiwan.

Figure S2 Field occurrence of the Szeleng sandstone in the northern Hsúehshan Range.

Figure S3 Foraminifers from the Szeleng Sandstone along the Northern-Cross-Island Highway section ((e) in Figure SI).

The supporting information is available online at csb.scichina.com and www.springerlink.com. The supporting materials are published as submitted, without typesetting or editing. The responsibility for scientific accuracy and content remains entirely with the authors. 